\title{
SPELEOGENESIS AND DEPOSITIONAL HISTORY OF PALEOKARST PHREATIC CAVES/CAVITIES; PODGRAD, SW SLOVENIA
}

\author{
SPELEOGENEZA IN SEDIMENTACIJSKA ZGODOVINA \\ PALEOKRAŠKIH JAM/VOTLIN PREŽETE CONE; \\ PODGRAD, JZ SLOVENIJA
}

\author{
Bojan OTONIČAR ${ }^{1, *}$
}

\begin{abstract}
UDC 551.44:551.35(497.434)

Bojan Otoničar: Speleogenesis and depositional history of paleokarst phreatic caves/cavities; Podgrad, SW Slovenia

The studied paleokarst corresponds to an uplifted peripheral foreland bulge when Upper Cretaceous diagenetically immature eogenetic carbonates were subaerially exposed, karstified and subsequently overlain by upper Paleocene/lower Eocene palustrine limestone.

Among the subsurface paleokarstic features, both vadose and phreatic forms occur. The phreatic caves/cavities include features characteristic of the mixing zone speleogenesis at the interface between freshwater (brackish water) lenses and the underlying seawater. They were found in various positions with respect to the paleokarstic surface, the deepest being about $75 \mathrm{~m}$ below the surface. Three indistinct horizons of cavities/caves and intermediate vugs were recognized. Subsequently, all cavities were completely filled with detrital sediments and speleothems in the phreatic and vadose zones. In general, the phreatic cavities of the lower two horizons are geopetally filled with mudstone derived from incomplete dissolution of the host rock and overlain by coarse-grained, blocky calcite. Shallower below the paleokarst surface, a large phreatic cave of the third horizon is filled with flowstone overlain by reddish micritic carbonate sediment with intercalated calcite rafts. In the upper part of the cave, sediments derived from the paleokarst surface are gradually becoming more abundant. Vadose channels, which may also intersect the cave sediments, are mainly filled with "pedogenic" material derived from the paleokarst surface. Immediately prior to marine transgression over the paleokarst surface, some cavities were filled with marine-derived microturbidites. In general, the diversity of cave fills and the amount of surface material decrease with distance from the paleokarst surface. Below the
\end{abstract}

\begin{abstract}
Izvleček
UDK 551.44:551.35(497.434)

Bojan Otoničar: Speleogeneza in sedimentacijska zgodovina paleokraških jam/votlin prežete cone; Podgrad, JZ Slovenija
\end{abstract} Raziskovani paleokras se je oblikoval na dvignjeni periferni izboklini, ko so bili diagenetsko nezreli zgornje kredni karbonati dvignjeni nad morsko gladino in zakraseli. Kasneje je bil ta zakraseli del periferne izbokline ponovno potopljen pod morsko gladino, paleokraško površje pa prekrito z zgornje paleocenskimi do spodnje eocenskimi palustrinimi apnenci.

$\mathrm{Na}$ raziskovanem območju se pojavljajo podpovršinske paleokraške oblike značilne tako za prežeto kot neprežeto hidrogeološko cono. Kraške jame in manjše votlinice prežete cone kažejo značilnosti speleogeneze $\mathrm{v}$ območju mešanja meteorne in morske vode. Pojavljajo se $\mathrm{v}$ različnih nivojih glede na paleokraško površje, najgloblje približno 75 $\mathrm{m}$ pod njim. Jame in votlinice so razporejene $\mathrm{v}$ tri neizrazite horizonte, vendar se tudi med njimi pojavljajo manjše pore in kanali, ki so večinoma nastali ali so bili vsaj deloma preoblikovani $\mathrm{z}$ raztapljanjem. Vse omenjene votline različnih dimenzij so bile kasneje $\mathrm{v}$ prežeti in neprežeti hidrogeološki coni popolnoma zapolnjene $\mathrm{z}$ večinoma drobnozrnatimi sedimenti in sigami. Na splošno so bile votline prežete cone spodnjih dveh horizontov geopetalno zapolnjene s karbonatnim blatom, ki je nastal kot posledica nepopolnega raztapljanja prikamnine votlin, preostanki nad drobnozrnatimi sedimenti pa $\mathrm{z}$ grobozrnatim mozaičnim kalcitom. V tretjem horizontu zapolnjenih votlin, plitveje pod paleokraškim površjem, se nahaja tudi velika jama, ki je tudi nastala $v$ prežeti coni. Ponekod v spodnjem delu vsebuje sigo, sicer pa je večinoma zapolnjena $\mathrm{z}$ rdečkastim karbonatnim mikritom $\mathrm{v}$ katerem so pogosta zrna, ploščice in svežnji plavajočega kalcita. V zgornjem delu velike jame postajajo sedimenti čedalje bogatejši z materialom, ki je bil v

\footnotetext{
${ }^{1}$ Karst Research Institute ZRC SAZU, Titov trg 2, SI-6230 Postojna, Slovenia; e-mail: otonicar@zrc-sazu.si

* Corresponding author
}

Received/Prejeto: 12.04 .2021

DOI: $10.3986 /$ ac.vi.9945 
paleokarst surface, the $\delta^{13} \mathrm{C}$ and $\delta^{18} \mathrm{O}$ values of a host rock and cavity deposits show good correlation with trends significant for meteoric diagenesis. It is shown that deposits associated with phreatic caves can be of great importance for the study of the speleogenetic, geomorphological and hydrogeological evolution of certain paleokarst regions.

Key words: paleokarst, cave sediments, stable isotopes, calcite rafts, Slovenia, Podgrad. jamo presedimentiran s paleokraškega površja. Tudi kanale neprežete cone, ki ponekod sekajo sedimente velike jame, v glavnem zapolnjuje "pedogeni" material presedimentiran s paleokraškega površja. Neposredno pred morsko transgresijo preko paleokraškega površja so bile nekatere votline zapolnjene $\mathrm{z}$ morskimi mikroturbiditi. Na splošno se raznolikost jamskih zapolnitev in količina s površja presedimentiranega materiala zmanjšujeta $\mathrm{z}$ oddaljevanjem od paleokraškega površja. V območju raziskovane zakrasele sekvence kažejo vrednosti stabilnih izotopov ogljika in kisika tako prikamnine kot sedimentov večjih in manjših votlin dobro korelacijo s trendi, značilnimi za meteorno diagenezo. Pričujoča raziskava potrjuje, da sedimenti, ki zapolnjujejo jame in druge, manjše, votline prežetih hidrogeoloških con, lahko igrajo pomembno vlogo pri razumevanju speleogenega, geomorfnega in hidrogeološkega razvoja nekaterih paleokraških območij.

Ključne besede: paleokras, jamski sedimenti, stabilni izotopi, plavajoči kalcit, Slovenija, Podgrad.

\section{INTRODUCTION}

Karst landscapes, with their surface and subsurface features and characteristic hydrology, have been of interest to naturalists for centuries, but the study of paleokarst gained prominence only when some ore deposits, water resources, and hydrocarbons were recognized to be associated with it. Additional interest in paleokarst studies was sparked by the introduction of sequence stratigraphy, since unconformities marked by paleokarst features represent important sequence boundaries in carbonate successions. Interest in the paleokarst of ancient carbonate platforms has also been accelerated by research of the diagenetic history of carbonate rocks, particularly in relation to hydrocarbon reservoirs.

In addition to the study of hydrogeological and general geomorphological characteristics, studies of recent, still active karstic hydrogeological systems usually focus on the origin and evolution of "common" phreatic caves that are later placed to epiphreatic and vadose zones (i.e., relict caves). In such studies, cave sediments are commonly used to determine the changing climatic conditions and the geological and geomorphological evolution of the studied karst areas during the still ongoing karst period (sensu Bosak et al. 1989). However, studies of paleokarst are mainly concerned with the nature of stratigraphic gaps that interrupt carbonate successions, surface deposits or soils (e.g., bauxite, clays), and with the diagenetic characteristics of the carbonate sequences that underlie and overlie the paleokarst surfaces. Description and interpretation of paleokarst caves/cavities and their deposits, as relatively thick sedimentary sections studied in terms of relative sea-level changes, are uncommon with a few exceptions (e.g., Csoma et al. 2004). Discussions of paleokarstic sediments tend to focus on the paleokarstic surface deposits and those that fill directly underlying vadose karstic depressions, channels and shafts, e.g., bauxite.

To be consistent with the definition (sensu Osborne 2000), paleokarst and related features are of course described primarily where the otherwise active carbonate platforms of warm tropical or subtropical climates were subaerially exposed, karstified and subsequently flooded during marine transgression. Thus, at least initially, young, diagenetically immature carbonates are subjected to karstification. To properly explain the paleokarst features of subaerially exposed ancient carbonate platforms, conceptual models other than "classic" karst and "common" caves must be considered. In recent decades, a number of karstic [i.e., "diagenetic karst conceptual models" (Esteban \& Klappa 1983; Choquette \& James 1988; Esteban \& Wilson 1993; Wright \& Smart 1994); "Caribbean karst conceptual model" (Mylroie \& Carew 1995a, b)] and speleogenic [i.e., Quintana Rootype caves (Thomas 1999; Smart et al. 2006; Kambesis \& Coke 2013); flank margin caves (Mylroie \& Carew 1995a, b)] conceptual models developed in the Caribbean, Bahamas, Florida and Yucatan. However, although individual types of specific deposits from these caves have been mentioned and described (e.g., Jones 1989; Smart et al. 2006), no continuous sedimentary sections have been published until recently (e.g., Fornós et al. 2009; 
van Hengstum \& Scott 2011; Collins et al. 2015; Kovacs 2017; van Hengstum et al. 2019). Thus, a lack of holistic studies of recent cave sediments in the above areas most likely also prevents a more comprehensive interpretation of paleokarst cave sediments.

The aim of the study is therefore to reveal and explain the facies of paleokarst phreatic cave sediments from the Podgrad area in SW Slovenia, in particular from a large, completely filled cave up to $4 \mathrm{~m}$ high, extending at least for several tens of metres along strike.
The facies are compared with cave sediments mentioned or described on some recently subaerially exposed parts of carbonate platforms of tropical/subtropical regions, and interpreted in relation to cave depositional and diagenetic environments (i.e., hydrogeochemical zones). It also discusses the dissolution and depositional evolution of hydrogeochemical zones in relation to large paleokrastic cave and some other smaller but common filled karst cavities in relation to relative sea-level changes through time.

\section{GEOLOGICAL SETTING}

The area of the village of Podgrad is a part of Podgrajsko Podolje, a karstic lowland plain in SW Slovenia, which extends from the Slovenian-Italian to the SlovenianCroatian border in NW-SE direction for about $30 \mathrm{~km}$ (Fig. 1). The investigated geological section is located on the southern flank of the Stari Grad (Old Castle) hill directly NE above the village. In geological terms, the Podgrajsko Podolje represents an anticlinorium dipping gently to the northwest (Placer 1981). The Lower Cretaceous to Cenomanian shallow-marine dolomites and limestones with intercalations of nondepositional coarse-grained calcareous dolomitic breccias in the central part of the anticline are overlain on both flanks by a sequence of upper Cenomanian to Santonian, predominantly shallow-marine limestones about $550 \mathrm{~m}$ thick (Fig. 2; Jež et al. 2011). The Cretaceous carbonate sequences are separated from the late Paleocene and early Eocene dark gray palustrine and early Eocene shallow marine foraminiferal limestone which pass into hemipelagic marl and deep marine siliciclastic flysch, by the discussed paleokarst unconformity (Fig. 2; Drobne 1977; Otoničar 2007).

Tectonically, the studied area belongs to the Komen Thrust Sheet, one of the outermost thrust units of the northwestern External Dinarides (Placer 1981, 1998). Komen Thrust Sheet comprises Cretaceous, predomi-

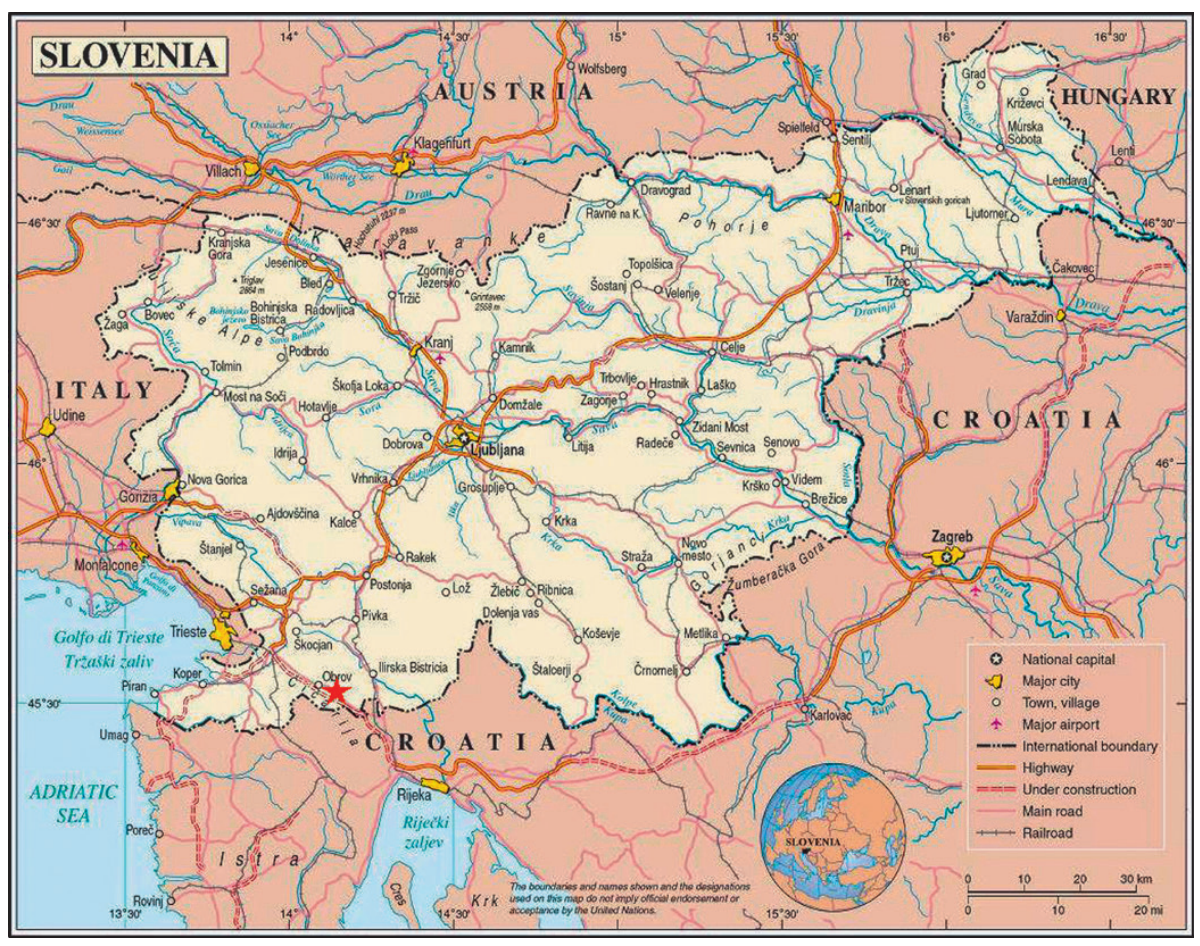

Fig. 1: Location map of Slovenia (CNations Online Project) and the studied area (asterisks). 
nantly shallow-marine deposits of the Adriatic Carbonate Platform (AdCP) (sensu Vlahović et al. 2005), overlain by Maastrichtian to Eocene deep-marine limestone and progradational hemipelagic marl and deep-water clastics (i.e., flysch). This part of the External Dinarides corresponds to the northern part of the Cretaceous passive margin AdCP and Upper Cretaceous to Eocene distant slope of the advancing synorogenic foreland basin, both occupying the northeastern part of the Adria microplate s.s. (sensu Stampfli et al. 1998).

In SW Slovenia and NW Croatia, a regional unconformity characterized by a karstified surface separates the passive-margin shallow-marine carbonate successions of various Cretaceous formations from the Late Cretaceous to Eocene palustrine and shallow-marine limestones of the synorogenic carbonate platform (Otoničar 2007). Thus, the discussed paleokarst and associated cave deposits correspond to an evolving peripheral bulge (or forebulge) migrating from the Campanian/Maastrichtian to the Middle Eocene across the northern sector of the AdCP (Košir \& Otoničar 2001; Otoničar 2007).

Both surface and subsurface paleokarst phenomena have been recognized at the unconformity (Otoničar 2007, 2008, 2016). Among the latter, both vadose and phreatic forms occur. Pedogenic features and enlarged root-related channels are characteristic of epikarst. Vadose channels, shafts and pits penetrate to tens of meters below the paleokarst surface, where they may 'merge' with originally horizontally oriented phreatic cavities. The phreatic cavities have been found in dif- ferent positions with respect to the paleokarstic surface, the deepest being about $75 \mathrm{~m}$ below it. Generally, only one distinct paleocave level occurs per site, although indistinct levels with spongy porosity and/or irregularly distributed cavities of different sizes, as well as reddish horizons up to several meters thick, were also noted in places. The cavities had been subsequently partially remodeled and completely filled with detrital sediments and speleothems in the phreatic, epiphreatic and vadose conditions. The cave-internal sediments and speleothems may also occur as clasts in deposits (usually breccias) that fill subsurface paleokarst cavities and cover the paleokarst surface. In general, the diversity of cavity-filling deposits and the amount of surface-derived material decrease with distance from the paleokarst surface.

In addition to the extent of the chronostratigraphic gap, which is typically unsynchronous over the area, the specific evolution and migration of the foreland also determine the range of maximum denudation and the general position of the water table below the subaerially exposed karst surface, and consequently a dissolution/depositional evolution of the phreatic and vadose cavities of the exposed carbonate succession. The effects of other variables, such as climate, tectonically or climatologically induced short-term relative oscillation of the water table, and the diagenetic history of the area, are also important in determining the course of karstification and deposition of cave sediments, but are only superimposed on the existing geotectonic framework.

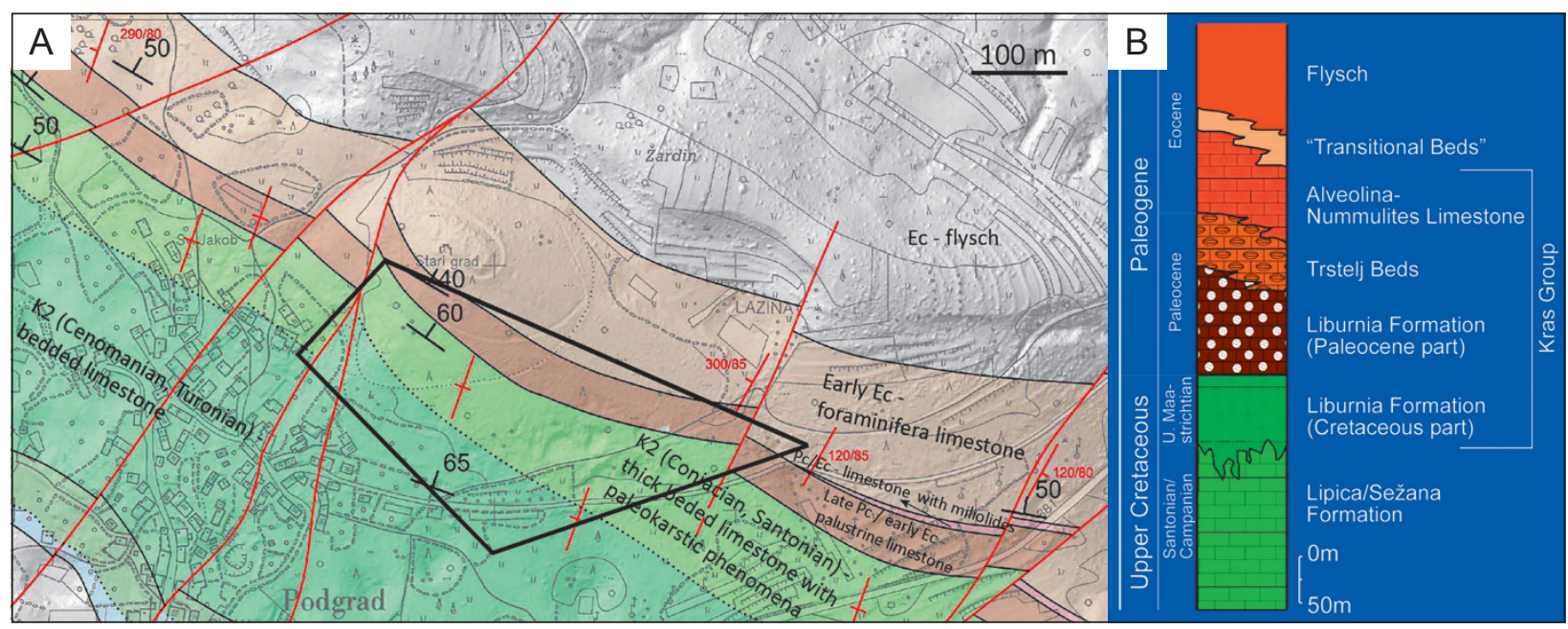

Fig. 2: A) Geological map of the studied area with the narrower study area marked (Jež 2011). B) Generalized geological column of the Upper Cretaceous-Eocene succession of the SW Slovenia showing the main lithostratigraphic units (adapted from Košir 2004). 


\section{METHODS}

In the field, detailed geological mapping at scales of 1:250 to $1: 1000$ and sampling of successive lithostratigraphic sections at scales of 1:50 and 1:100, with particular reference to paleokarst phenomena was carried out. These methods were combined with detailed sketches and photographs of paleokarst phenomena. The photographs also served as a basis for detailed sketches of the lithological characteristics of the cave sediments and for marking the sampling sites.

The present study is based on detailed petrographic analyses of the sedimentary and diagenetic characteristics of sedimentary rocks associated with paleokarst caves, supplemented by stable isotope analyses of carbon and oxygen.

Rock plates with an average size of about $50 \mathrm{~cm}^{2}$ were prepared from about 350 samples. All plates were washed in highly dilute hydrochloric acid for better observation and examined with a binocular microscope. More than one hundred thin sections were prepared from the selected plates for standard petrographic and cathodoluminescence analyses.

A Technosyn ${ }^{\circledast}$ cold cathodoluminescence luminoscope (model CITL CL8200 MK4) with a $14 \mathrm{kV}$ electron beam and an electron current of 350-400 $\mathrm{AA}$, mounted on a Nikon Eclipse E600 biological petrographic microscope, was used for cathodoluminescence studies. All thin sections examined in transmitted light and cathodoluminescent light were photographed using a Nikon Coolpix 990 digital camera.

Seventy samples were analysed for the isotopic composition of carbon and oxygen. Microsamples for isotopic analysis were obtained from rock slabs, most of which corresponded to the thin sections. Based on petrographic and cathodoluminescent observations, different depositional and diagenetic phases were sampled using the dental drill rig available at Ivan Rakovec Paleontological Institute ZRC SAZU. In this way, 10 to $100 \mu \mathrm{g}$ of powdered samples of areas up to $1 \mathrm{~mm}^{2}$ were obtained.

The $\delta^{13} \mathrm{C}$ and $\delta^{18} \mathrm{O}$ isotopic analyses were performed in the Stable Isotope Laboratory of the Department of Earth and Atmospheric Sciences at Saint Louis University, USA. Isotopic ratios are given in parts per thousand according to the VPDB standard. Standard deviations for the oxygen isotope values of the internal standards are $0.19,0.18$, and $0.14 \%$ in the three experiments and less than $0.11 \%$ in the other five experiments, and less than $0.09 \%$ for carbon.

The qualitative and semi-quantitative mineral compositions of 11 selected samples of cave-related deposits were determined using powder X-ray diffraction. The samples were analyzed using a Philips diffractometer at the Department of Geology, Faculty of Natural Sciences and Engineering, University of Ljubljana, Slovenia and a Bruker D2 PHASER diffractometer at the Karst Research Institute ZRC SAZU, Slovenia. Recording conditions: Anode - CuKa, el. voltage - $40 \mathrm{kV}$, el. current - $30 \mathrm{~mA}$, $\mathrm{Ni}$ filter and proportional counter and automatic divergence valve. The recording was performed continuously, at a rate of $2^{\circ} 2 \Theta / \mathrm{min}$ in the range of a $2 \Theta$ angle from $2^{\circ}$ to $70^{\circ}$.

Elemental analyses were performed on the Bruker S6 Jaguar WDXRF at the Karst Research Institute ZRC SAZU, Slovenia.

\section{RESULTS}

\section{HOST ROCK}

The studied terrain above the Podgrad consists of stratified Turonian to thick-bedded Coniacian/Santonian shallow-marine limestones, which can be roughly divided into a few depositional sequences. The lowest sequence is dominated by peloidal grain-supported limestone deposited on subtidal to occasionally intertidal peloidal shoals formed between open and closed lagoon. The upper parts of its last few parasequences contain increasingly pronounced pedogenic modifications and represent the sequence boundary. It is overlain by mud-supported miliolid-ostracod-algal limestone of a closed lagoon, which alternates with foraminiferal-peloidal grain-supported limestone of an open side of peloidal shoals further up in the section, which eventually becomes dominant over the mud-supported facies. Although features characteristic of intertidal environments have occasionally been found in the mud-supported facies (e.g., fenestrae), the frequency and complexity of phenomena characteristic of short-term subaerial exposure events and associated pedogenic modifications (e.g., keystone vugs, rhizoliths, pedogenic peloids and oncoids, Microcodium grains and rosettes...), increase in grain-supported facies where the composite sequence boundary has been determined. 


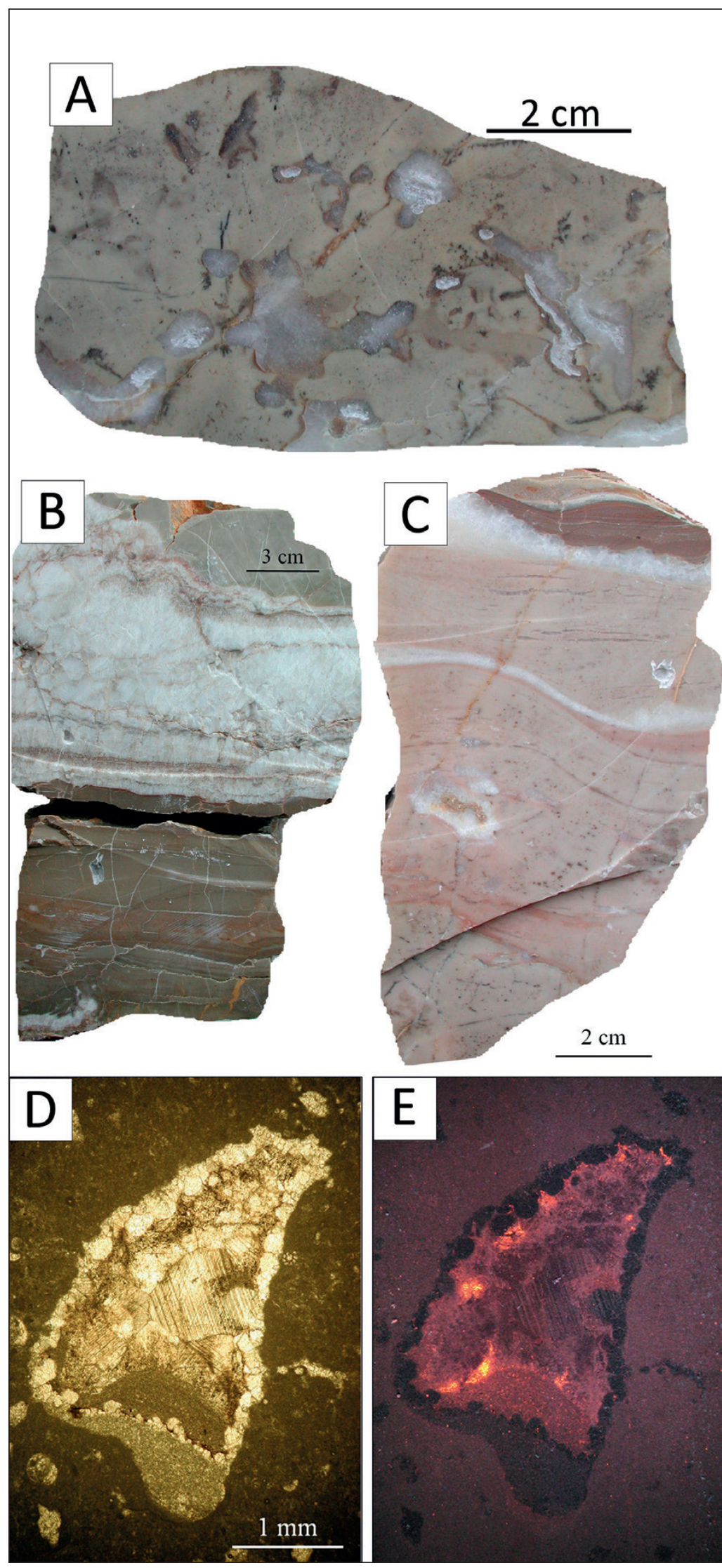

Fig. 3: Cavities of the first and second cavity horizon. A) Selectively dissolved primary marine internal sediments of the bioturbation burrows. The dissolution vugs were subsequently filled with columnar, coarse-grained brackish or freshwater sparite. Note the partially oxidised disseminated pyrite, which gives the sample a mottled appearance. B) Cavities up to $1 \mathrm{~m}$ wide occur between 60 and $75 \mathrm{~m}$ below the paleokarst surface (first horizon). They are filled with geopetally deposited grey micrite of reddish hue overlain by white coarse-grained calcite spar. C) A decimetre-scale cavity of the second horizon filled with undulating laminated pinkish micrite with intercalated sparite is overlain by bladed to columnar sparite fringe and reddish brown laminated silty mudstone and yellowish brown laminated and graded sandstone, siltstone and mudstone. $D, E)$ The millimetre- to centimetre-scale cavities of the first horizon are often filled with several generations of internal geopetal sediments and cements. Different depositional phases are also reflected in different luminescence colours. 
Complexity often results from features indicative of exposure to the seafloor (i.e., hard- and firm-grounds) overwritten by dissolutional and/or pedogenic modifications (i.e., composite surfaces after Immenhauser et al. $2000 \mathrm{a}, \mathrm{b})$. The final sequence below the main paleokarst surface again consists mainly of miliolid-ostracod-algal limestone of a closed lagoon, which on approaching the paleokarst surface shows no significant differences in syn-depositional textural or structural characteristics, except of course in the features already related to the discussed paleokarst. As can be seen from the above, variably shaped and filled fenestrae, troughs, channels, cavities, pores and caves occur virtually throughout the geological section studied and become particularly common above the first sequence boundary. Some of them were defined as syndepositional features formed before the main exposure of the area to the land surface (Otoničar 2006). During the successive phases of meteoric diagenesis and karstification, some cavities were reshaped and filled. Although various filled pores and cavities are found virtually throughout the profile, larger, unfilled selective, decimeter- and metre-sized cavities are concentrated in three rather indistinct horizons: 1) at 75 to 60 metres, 2) at 35 to 30 metres, and 3) at 25 to 15 metres below the paleokarst surface. In the upper (third) horizon about 20 metres \pm 2 metres below the paleokarst surface, the "Large Cave" (LC) occurs. Although the decimetresized caves of the first and second horizons differ slightly in shape and size and occur in quite different host rocks (muddy texture of the first horizon vs. granular texture of the second horizon), they are both filled with similar depositional succession and surrounded by smaller millimetre- to centimetre-sized gullies and troughs. At least some of the very irregularly branched gullies, up to a few centimetres wide, were originally formed as bioturbation trenches and subsequently filled with marine silty micrite including marine peloids and fossils (Fig. 3A). These features are more common and larger within the grain-supported facies of the second horizon, where the depositional sequence is more regularly interrupted by discontinuity surfaces (see above).

In the first two horizons, decimetre-sized cavities are typically geopetically filled with a massive and laminated micrite, followed by coarse-grained sparite, which may completely fill the upper part of the cavities (Fig. $3 \mathrm{~B})$. In the second horizon, the residual cavities are commonly surrounded by columnar and foliated to isometric coarse-grained sparite and filled with laminated and graded calcareous sandstone, siltstone, and mudstone with some clay minerals (e.g., kaolinite) and Fe oxides (e.g., goethite) (Fig. 3C). Here, but also within individual smaller jars, some sandy crystalline particles resemble grains related to calcified roots (e.g., Microcodium grains).
Millimetre- and centimetre-sized cavities are filled with various sets of internal sediments and cements, the complete paragenetic sequence of which rarely occurs. Thus, even in thin section, adjacent troughs and channels are often filled with different sequences of sediments and cements. The ideal paragenetic sequence contains geopetally deposited grey micrite in the lower part, followed by a non-luminescent (NL) seam of clear isometric to foliated sparite and geopetally deposited brownish silty micrite (Fig. 3D, E). The remaining cavity is filled with white, impure, coarse-grained mosaic sparite with sedimentary inclusions that has a medium to light orange or inhomogeneous intrasectoral dull brownish-orange luminescence (often with medium to light orange patches) (Fig. 3E), indicating neomorphic alteration of the original internal micrite in meteoric or brackish water, in agreement with the isotopic composition (see below).

It is important to note that between about 30 to 45 metres below the paleokarst surface (i.e., roughly coincident with the second horizon) there are patches, spots and dendrites of oxidised disseminated pyrite which give the limestone a mottled appearance (Fig. 3A). They precede the precipitation of some coarse-grained, whitish and columnar fringed and equant calcite cements from centimetre-scale dissolution channels/vugs and the second generation of internal sediments (see above) (Fig. 3A).

The paleokarst surface as a large-scale topography or stratigraphic and the "mega" sequence boundary occurs as a gently undulating relief between Cretaceous and Tertiary limestones, both showing similar dip of strata. However, the upper 25 metres of the underlying karstified formation (to about the base of the LC) is intertwined with darker brownish and reddish patches in lighter limestone representing neomorphosed host rock and vadose subvertical channels, shafts, pits, root casts etc., filled with calcareous and clayey sediments related to pedogenic processes on the paleokarst surface. However, these features are beyond the scope of this article.

\section{ISOTOPES}

The stable isotope compositions of carbon and oxygen of the host rock, internal sediments, and cements decrease systematically toward the paleokarst surface (Fig. 4). Each successive sequence, defined by sequence boundaries and/or the cavity horizons discussed above, reflects the characteristic isotopic composition not only of the host rock but also of the cavity-internal sediments and cements (Fig. 4). In general, $\delta^{18} \mathrm{O}$ values are relatively constant with little variation with respect to stratigraphic position, whereas $\delta^{13} \mathrm{C}$ values vary much more (i.e., meteoric calcite line after Lohmann 1988). To estimate the range of deviations from the average composition of calcite precipitated from the Late Cretaceous marine 


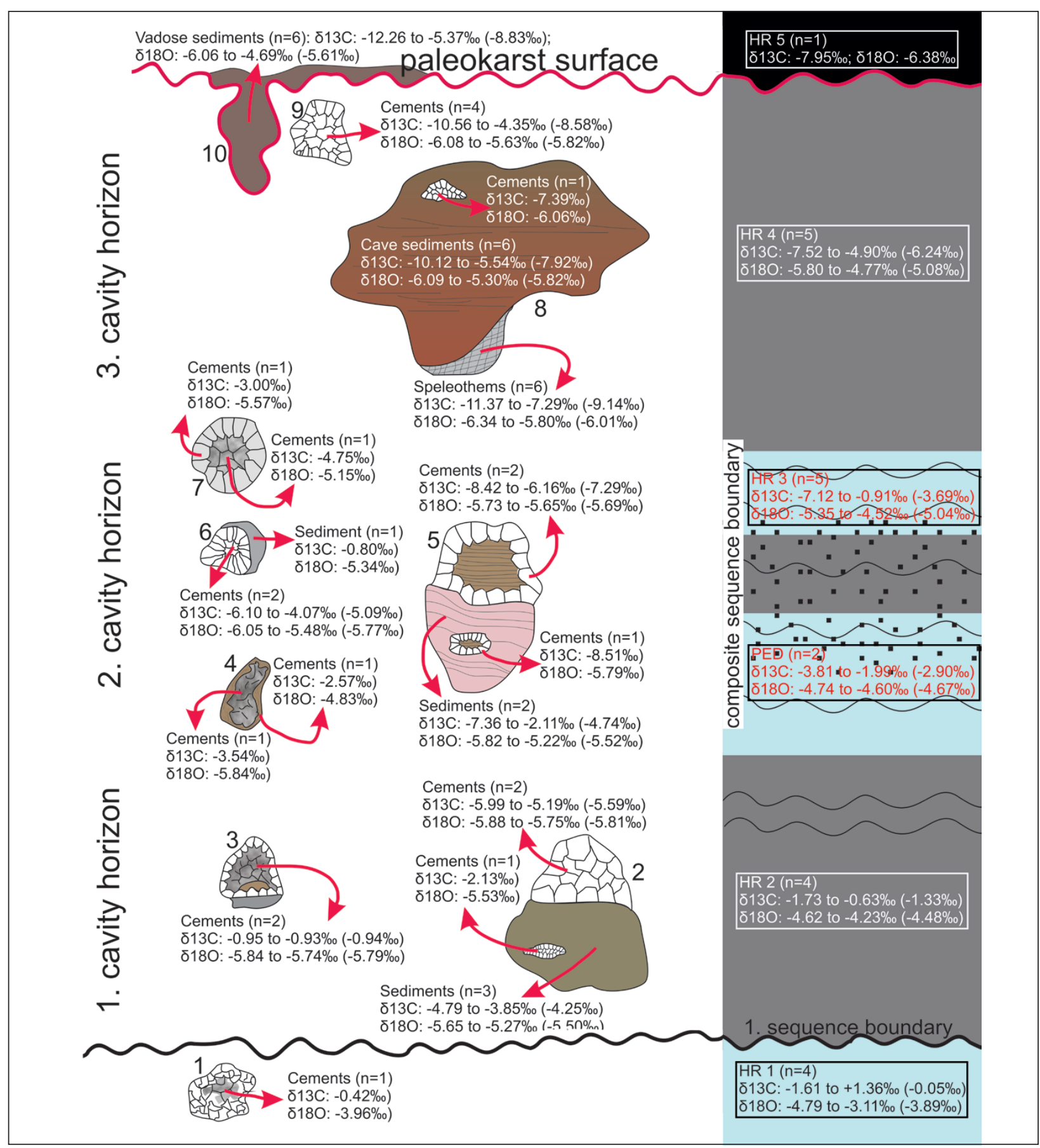

Fig. 4: Schematic sketch of the basic host rock and cave/cavity depositional sequences with their isotopic composition (isotopic values in parentheses represent the mean values; $n=$ number of analysed samples). The right side of the sketch shows the predominant lithofacies associations (grey colour: mud-supported miliolid-ostracod-algal limestone; blue colour: grain-supported peloidal limestone; wavy lines mark short-term exposures on the seafloor, on the land surface, or a combination of both; HR = host rock; PED = pedogenically modified limestone; black squares represent horizon with oxidised pyrite). The left side of the sketch shows the main types of vugs, cavities and caves with the most characteristic fillings. 1) Vugs associated with decomposition of Lithocodium/Bacinella microbial encrustations. 2) Decimeter-sized dissolution cavities. 3) Millimetre-to centimetre-sized bioturbation burrows. 4) Millimetre-sized rhizoliths not related to the main paleokarst period. 5) Centimetre- to decimeter-sized dissolution cavities with secondary dissolution vugs. 6) Selectively dissolved fillings of millimetre- to centimetre-sized bioturbation burrows. 7) Millimetre- to centimetre-sized dissolution enlarged bioturbation burrows and dissolution vugs. 8) The Large Cave. 9) Centimetre- to decimeter-sized dissolution cavities and intrarudist pores. 10. Vadose cavities. The sketch and depicted depositional, dissolution, and other features are not to scale. 


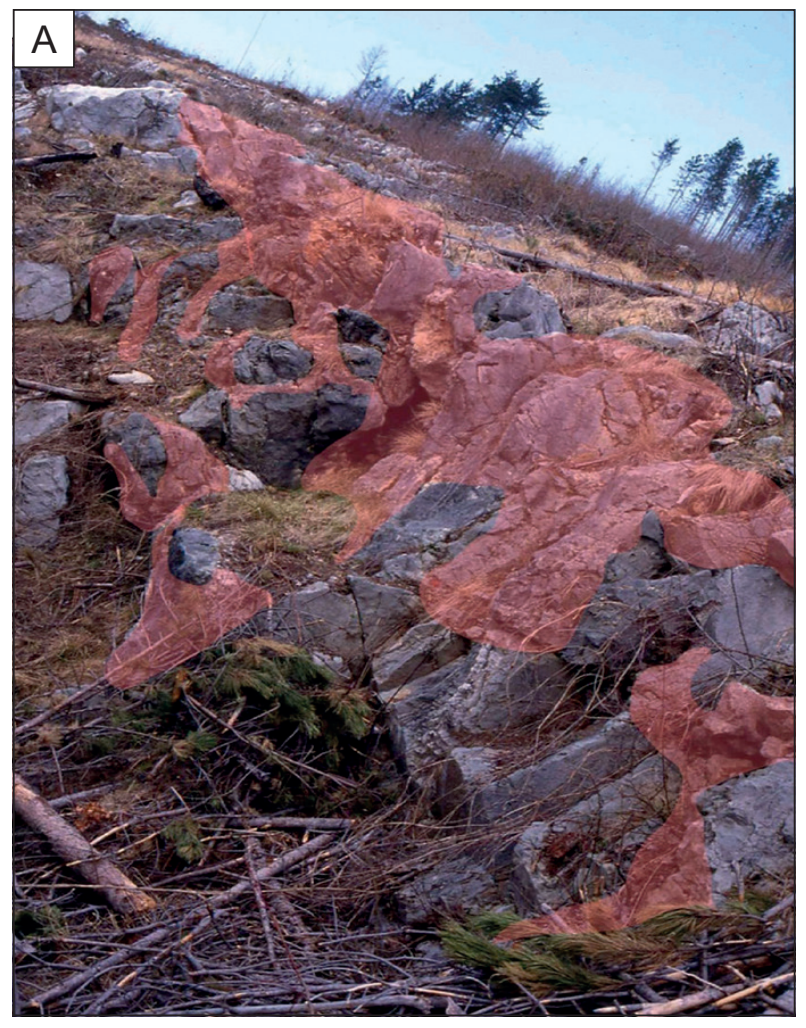

waters of the region, the highest $\delta^{13} \mathrm{C}$ and $\delta^{18} \mathrm{O}$ values of neomorphically unaltered marine host rock isotopically stabilised in ambient seawater can be used as an approximation. On the other hand, the lowest $\delta^{13} \mathrm{C}$ and $\delta^{18} \mathrm{O}$ values of flowstone undoubtedly precipitated from meteoric water can be used to estimate the deviations from the average composition of freshwater calcite precipitated from the Late Cretaceous meteoric water of the area. The highest $\delta^{13} \mathrm{C}(+1.36 \% 0)$ and $\delta^{18} \mathrm{O}$ values $(-3.11 \% 0)$ of the unaltered host rock occur in the lowermost part of the geologic section (Fig. 4), below the first sequence boundary, and agree relatively well with the average values of the Late Cretaceous shallow-marine limestones (sensu Veizer et al. 1999), whereas the lowest $\delta^{13} \mathrm{C}(-11.37 \%$ ) and $\delta^{18} \mathrm{O}(-6.34 \%)$ values of flowstone as a freshwater vadose deposit provide an estimate for the composition of the calcite precipitated from the local freshwater.

On average, the $\delta^{13} \mathrm{C}$ values of NL isometric and fringing columnar to bladed sparite in the central parts of millimetre- to centimetre-scale channels and vugs are lower than dull luminescent isometric mosaic sparite, whereas the $\delta^{18} \mathrm{O}$ values are similar (Fig. 4). Although also consistent with the general trend in distance from the paleokarstic surface, $\delta^{13} \mathrm{C}$ and $\delta^{18} \mathrm{O}$ values of internal sediments (i.e., cavity and cave sediments) are generally much lower in sediments associated with the paleokarstic surface and vadose cavities than in those associated with smaller cavities of the first and second horizons, with
Fig. 5: Filled paleokarstic caves and cavities of the third horizon (Photo: B. Otoničar). A) A central part of the filled large paleokarstic cave (LC). The sediments filling the cave are artificially highlighted. The central part of the cave reaches a height of about 4 metres. B) Smaller filled cavity probably represents part of a channel branching off from the LC. However, it is possible that such cavities and certain sediments did not all form or deposit at the same time, during the same paleokarst dissolution/depositional phase (Photo: B. Otoničar).

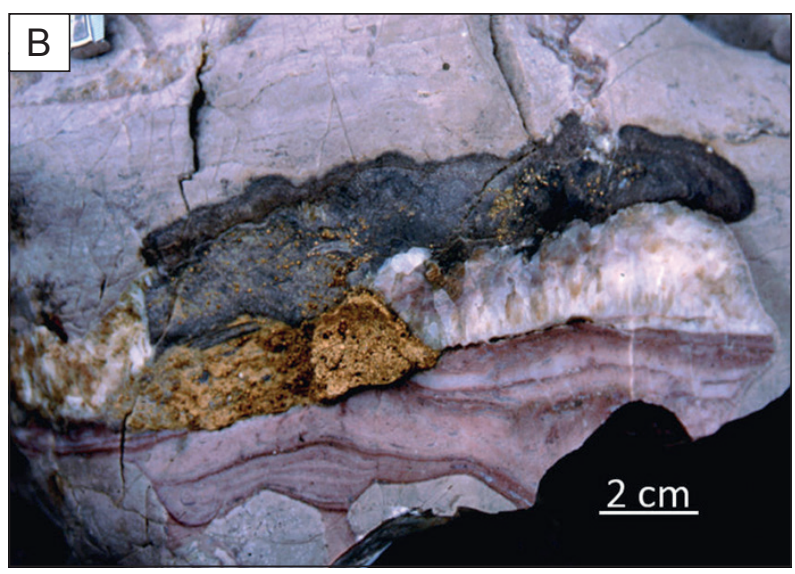

some exceptions (Fig. 4). The isotopic composition of the internal sediments of the LC is comparable to that of the paleokarst surface and vadose cavities, but $\delta^{13} \mathrm{C}$ values are about $1 \%$ higher and $\delta^{18} \mathrm{O}$ values are about 0.2 $\%$ o lower on average. Furthermore, the lowest both $\delta^{13} \mathrm{C}$ and $\delta^{18} \mathrm{O}$ values among all the "stratigraphic" groups of samples analysed have, on average, speleothems, all associated with the LC (Fig. 4; see below).

\section{"LARGE PALEOKARST CAVE"}

The main part of the large filled paleokarst cave occurs between about $20 \pm 2 \mathrm{~m}$ below the paleokarst surface, although smaller patches of sediments similar to those filling the LC are found between about 35 and $15 \mathrm{~m}$ below the paleokarst surface.

The LC is predominantly filled with reddish-coloured, fine-grained carbonate sediments, while speleothems are quantitatively less important. Especially the upper parts of the cave sediments are characteristically pedogenically modified. Only in the upper part of the cave section sandy siltstone and yellowish-brown breccia occur. Breccia is also found near the lower part of the LC, but due to its fragmentary preservation, its origin and relationship to the other cave sediments is not entirely clear. The cave sediments were subsequently partially eroded and overlain by yellowish-brown silty to sandy sediments reminiscent of pedogenically modified sediments of the vadose cavities. 


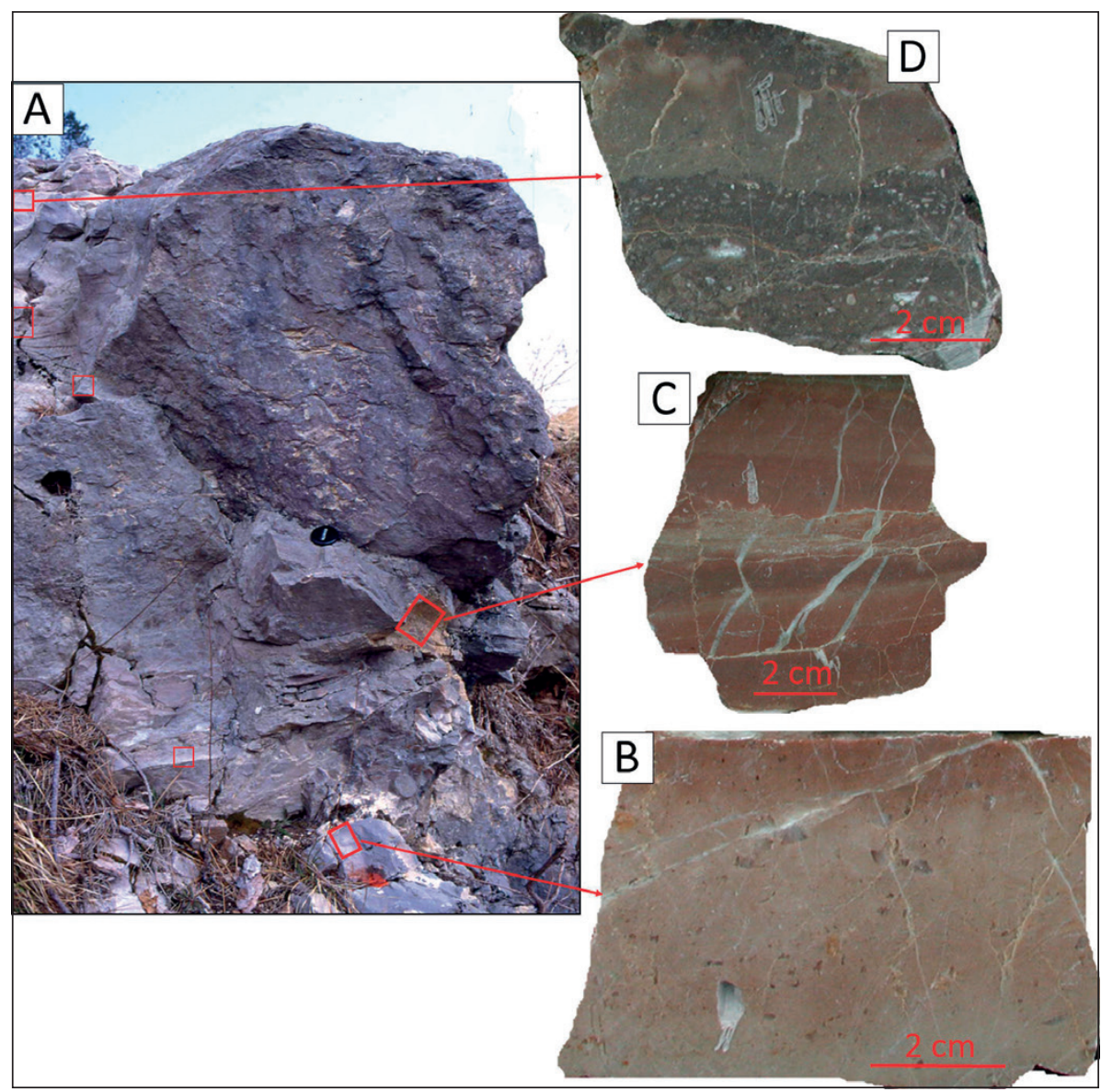

Fig. 6: The main sequence of paleokarstic cave deposits. A) The red cave sediment of the central part of the $L C$. The red rectangles indicate sampling sites. The diameter of the photographic lens cover is about 6 $\mathrm{cm}$ (Photo: B. Otoničar). B) In the lower part of the cave depositional section, the sediments are massive and slightly lighter brownish-red (see also Fig. 7A). C) Toward the upper part of the cave section, the sediment gradually becomes more distinctly laminated and darker brownish-red. The lamination is the result of deposition of sediment with different particle size and intercalated bundles of calcite rafts. D) In the uppermost part, the cave sediment is often dark grey with a brownish-reddish hue and inhomogeneous. The inhomogeneity is the result of deposition of different materials and different intensity of in-situ modifications of the sediment (pedogenic modifications, dissolution, cementation, etc.).

\section{CAVE PATTERN AND MORPHOLOGY}

On the present land surface, the cave appears as an irregular, elongate, slightly reddish and brownish sedimentary body that lies unconformably within the light grey miliolid-ostracod-algal mudstone and wackestone (Fig. $5 \mathrm{~A})$. The cave walls or contacts of the reddish sediment with the greyish host rock are irregular but sharp (Fig. $5 \mathrm{~A})$. Locally, the walls are cut by widened cracks and cavities ranging in size from centimetres to decimeters. Smaller channels and cavities of centimetre and decimetre dimensions occur frequently near the LC. At least in part, they are filled with similar sediments as the LC. We suspect that they mostly represent sections of the LC (Fig. 5B), although a relation to some other dissolution phase cannot be entirely ruled out.

The cave is composed of several interconnected sections, between which are the remains of a grey host rock (Fig. 5A). Although the sediments, which resemble those of $\mathrm{LC}$, are distributed in a vertical span of about 20 metres, the central part of the cave does not exceed a height of four metres (Fig. 5A). In the outcrop, we can follow the central part of the cave continuously approximately parallel to the stratification for a length of more than 50 metres, without interrupting the cave sediments. How- ever, within this horizon, remnants of cave sediments occur over a length of about 300 metres throughout the studied area. Although the geometry of the cave is somewhat speculative due to the two-dimensional outcrop, it is evident that it has a much greater horizontal than vertical extent.

\section{CAVE DEPOSITS}

Fine-grained, reddish-coloured, calcareous cave sediments

Most of the cave is filled with reddish fine-grained carbonate sediments (Figs. 6A-D). In the upper part of the cave section, the sediments are often dark brownish-grey and show some characteristics of pedogenic modification (Fig. 6D).

Among the fine-grain ed cave sediments, reddish calcareous cave micrites and silty micrites predominate. Their shades range from light brownish pink to medium brownish red to dark brick red (Figs. 6A-C). Despite the predominance of the above fractions, the grain size of the sediments is not uniform. Throughout the cave sedimentary section, micrite and silty micrite alternate with clotted micrite, siltstone, and sandy siltstone (Figs. 7AI). Since they are mostly composed of fairly pure calcite, 

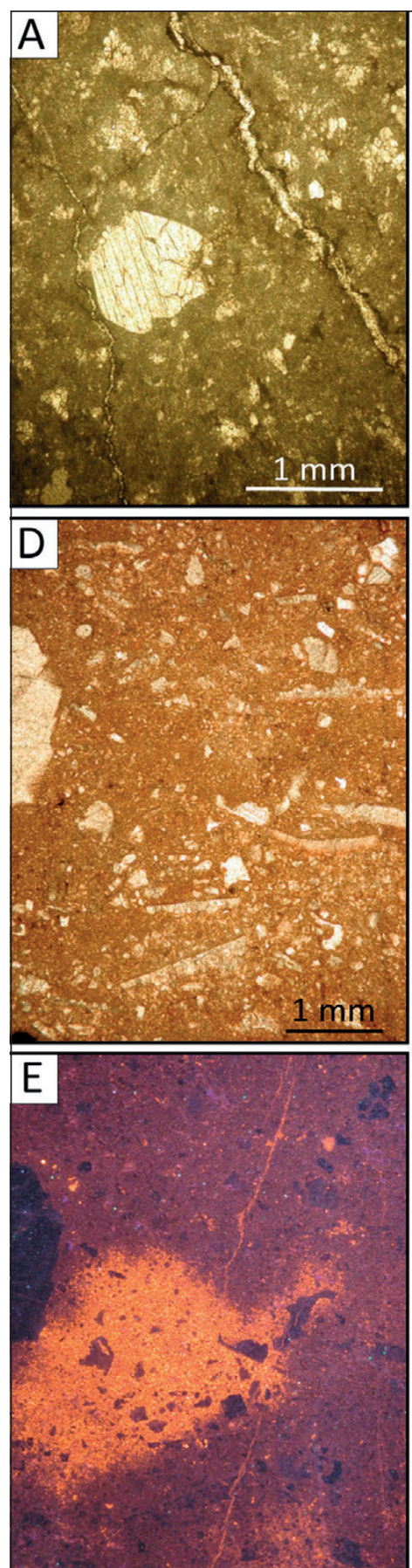
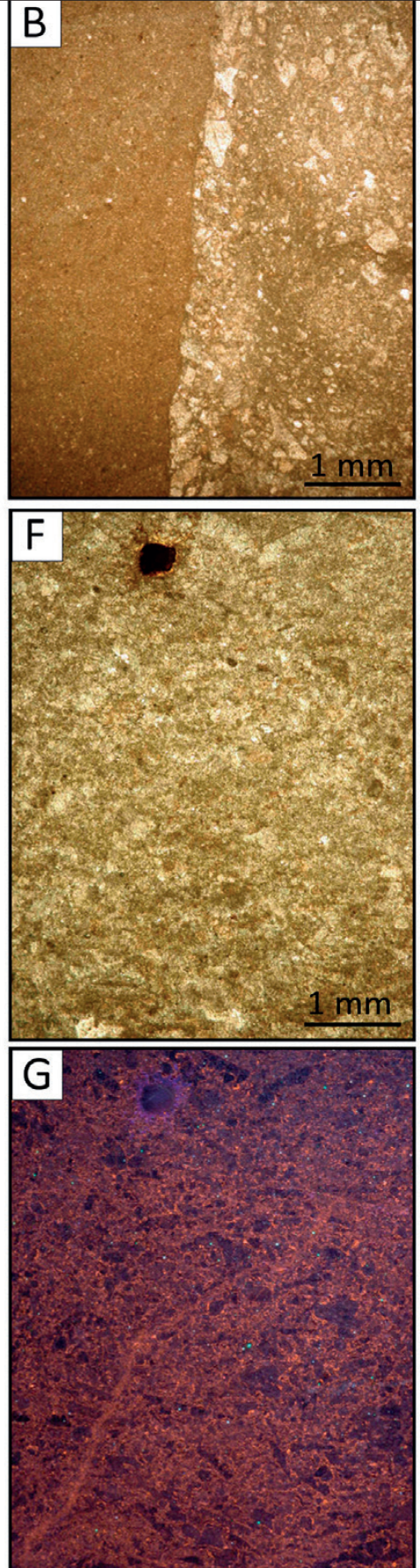
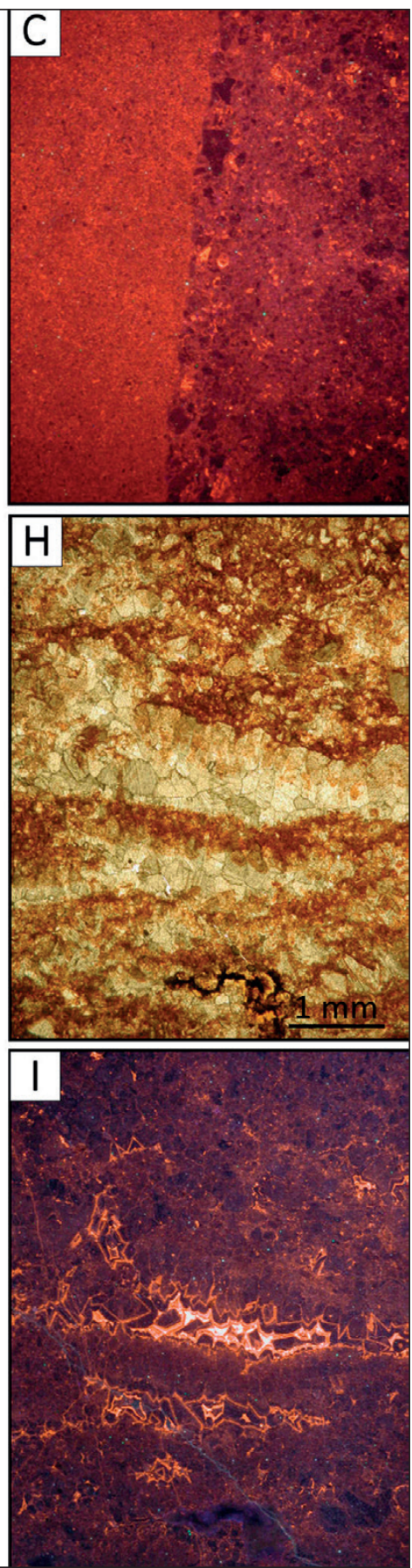

Fig. 7: Fine-grained sediment from LC section. With the exception of Fig. 7A, all other figures represent duplicate photomicrographs taken in transmitted and cathodoluminescent light. A) Sand-and silt-sized grains of crystalline calcite (sparite cement, disaggregated calcite rafts, and other speleothems) embedded in the slightly clotted micrite (photomicrograph of the cave sediment on Fig. 6B). B, C) A crack in the fine-grained silty micrite was synsedimentary filled with calcareous sandy silt (speleothems and cements - NL grains; grains resemble Microcodium grains or calcified root cells - grains with the orange luminiscent rim) (third sample from top on Fig. 6A). D-I) The series of photomicrographs shows the structural and textural differences of the cave sediments at the level of a hand sample. D, E) In the reddish silty micrite, calcite rafts predominate among the larger grains. Grains of disaggregated flowstone and cements also occur. Note the orange luminescence indicating selective neomorphic alteration of the micrite, which is not visible in transmitted light. F, G) Recrystallized clotted micrite/microsplite. Primary grain composition (i.e., non-luminescent calcite rafts) is still visible under cathodoluminescence. $H, I)$ Red clotted micrite (cave sediment) with secondary pores subsequently filled with concentrically zoned, bladed, and isometric spar shows increasingly anoxic conditions. 
they can also be called limestones of the "mudstone", "wackestone" and more rarely "packstone" textural types. The somehow different origin or provenance of the micrite is also reflected in different luminescence colours of the individual layers or groups of layers (Figs. 7C, E, G, I). Although in general the relatively homogeneous character of the individual layers indicates limited neomorphic alteration, the locally clotted character of the micrite/microsparite and patches of bright luminescence within the dull luminescent micrite suggest some degree of neomorphic alteration (Figs. 7F, G). Locally, secondary pores occur within the cave sediments (Figs. 7H, I). Crystalline calcite grains of a silty to sandy fraction predominate among the allochems. Leached and resedimented grains of cements/neomorphosed host rock and speleothems occur among the crystalline clasts. Among the latter, fragments of calcite rafts are significant (Figs. 7D-G). Towards the upper part of the cave section, particles resembling Microcodium grains or calcified root cells gradually become more abundant. The crystalline grains are predominantly sharp-edged and inhomogeneously "scattered" over the micrite matrix. Occasionally, laterally confined deposits or lamellae of small, less than $1 \mathrm{~mm}$, red, clayey-ferrous(?) ooids occur (Fig. 5B). Because similar ooids fill some secondary channels younger than the cave sediments
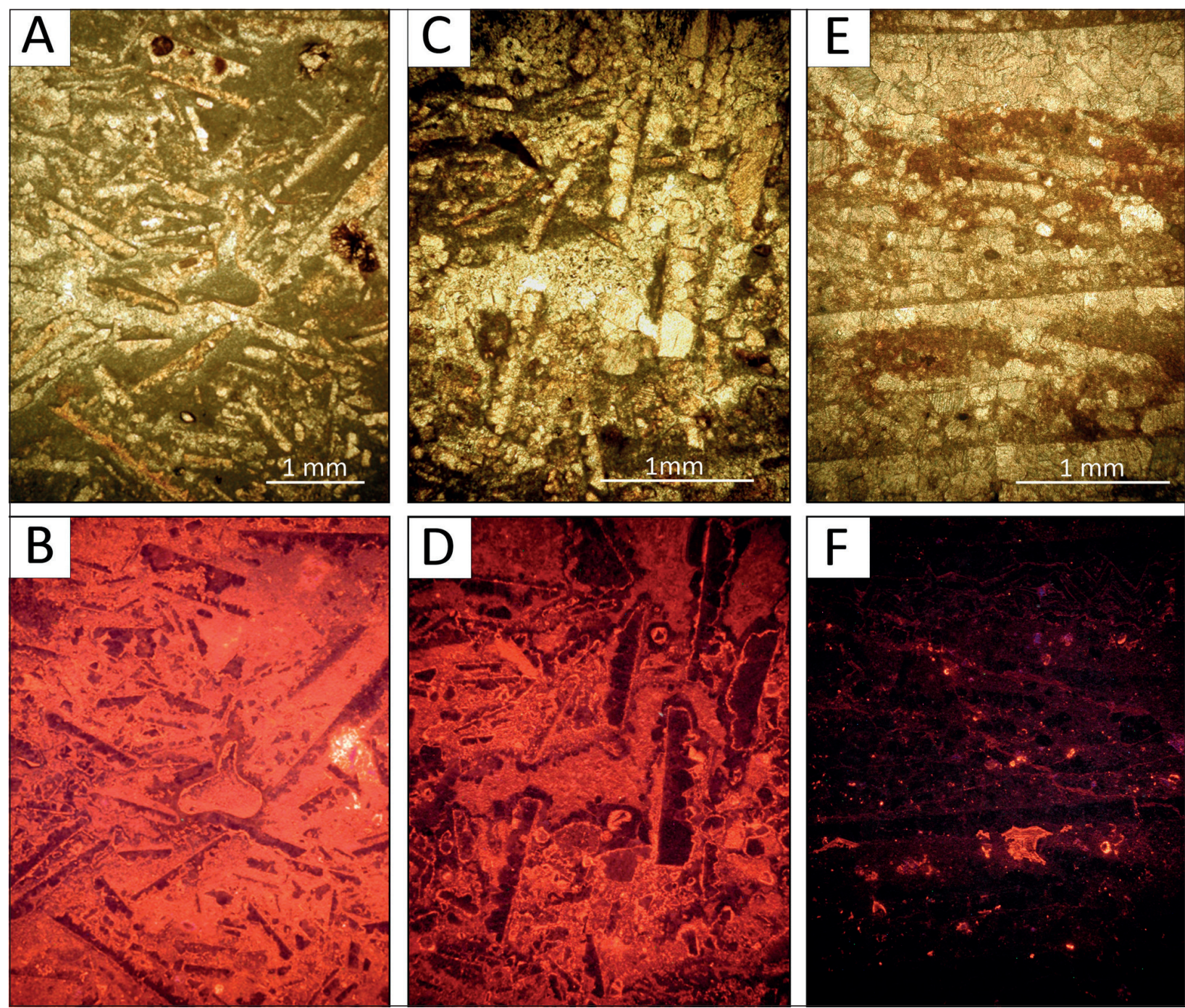

Fig. 8: Duplicated photomicrographs of calcite rafts taken in transmitted and cathodoluminescent light. A, B) Calcite rafts - some coated with micrite - of the upper part of the LC are often arranged in a "house of cards" structure. Intergranular pores are filled with a greyish micrite, although some shelter porosity was partly occluded by calcite sparite. Secondary pores lined with a thin sparite fringe and filled with similar micrite to the intergranular pores are clearly visible, especially in cathodoluminescent light (B). C, D) Note that some calcite rafts are coated with thin orange luminescent micrite fringe, followed by NL calcite crystals. NL crystals also surround secondary vugs filled with medium orange luminescent unclear coarse-grained sparite. E, F) Bundles of calcite rafts locally enclose larger rafts subsequently thickened by epitaxial growth of calcite crystals, oscillatory zoned in cathodoluminescent light. 
under consideration, it is not entirely clear whether these grains do not simply adhere to the walls of secondary cracks and channels that intersect the cave sediments. Mineralogical analyses of two cave sediments from the main cave section (samples on Fig. 6C and Fig. $6 \mathrm{D})$ yielded no minerals other than calcite. However, elemental analyses of otherwise only one sample (Fig. $7 \mathrm{~B}$ ) indicate the possible presence of a small amount of $\mathrm{Al}$ silicates and Fe oxides. Another important characteristic revealed with elemental analysis of this sample is the small amount of $\mathrm{Sr}(90 \mathrm{ppm})$.

The reddish micritic sediments are mostly dull to medium brownish and orange luminescent, whereas the silty and sandy crystalline clasts are predominantly nonluminescent. The clayey ferrigenous (?) ooids are also predominantly non-luminescent, with only the individual ones surrounded by a blue luminescent halo. This luminescence resembles that of some brownish seams and fills of tiny pores, yellowish crystals, and some peloids, especially near the paleokarst surface (i.e., one of the youngest generations of sedimentary features associated with paleokarst considered here). The luminescence colours of the matrix can be very inhomogeneous in places, even if no differences are seen in transmitted light (Figs. 7D, E).

Calcite rafts are discussed among the fine-grained cave deposits because they occur as individual more or less disaggregated crystalline grains within the reddish micritic matrix or alternating with micrite in the form of bundles less than a millimetre to a few centimetres thick. Even in such cases, the amount of rafts rarely exceeds the amount of micrite (Fig. 8). In the field, they are difficult to detect within reddish sediments because the individual rafts are very thin. Where the amount of rafts is relatively high, the rock is usually somewhat lighter and brownish grey in colour (Fig. 6C).

The average length of the rafts is about $1.5 \mathrm{~mm}$ and the thickness about $0.1 \mathrm{~mm}$ (Figs. 8A-D), but individual rafts may exceed $1 \mathrm{~cm}$ in length (Figs. 8E, F). Especially where the proportion of rafts exceeds the proportion of micrite, the rafts are often difficult to identify because of neomorphic alteration (Figs. 7F, G). Among the wellpreserved calcite rafts, single sided (sensu Jones 1989), with a flat and a serrated surface, predominate (Fig. 8). Some rafts are overgrown with a thin micrite fringe (Figs. $8 \mathrm{~A}-\mathrm{D}$ ), which is often poorly expressed due to the placement of the rafts within the micrite matrix. The calcite rafts are mostly non-luminescent (Figs. 8E, F), whereas the micrite fringe and surrounding matrix are medium, rarely dull, orange luminescent (Figs. 8A-D). Some rafts have been thickened by secondary precipitation of NL calcite crystals over the micritic fringe (Figs. 7C, D) or by epitaxial growth over the lower serrated part of the rafts (Figs. 7F, G).

The rafts are often arranged in a "house of cards" structure with a micrite in the intergranular pores (Figs. $8 \mathrm{~A}-\mathrm{D})$. Although the secondary pores often selectively avoid the calcite rafts (Figs. 8C, D), they sometimes cut into both the rafts and the micrite matrix. The pores are often surrounded by a thin continuous fringe of bladed and isometric NL rarely medium orange luminescent sparite, while the interior is filled with impure dull to medium orange luminescent blocky sparite or micrite resembling intergranular micrite but brightly luminescent (Figs. 8A-D).

In the upper part of the cave, grains whose origin is related to pedogenic processes become increasingly prominent. The micrite matrix is dominated by partially dissolved(?), silty and fine-grained sand particles resembling Microcodium grains, or calcified root cells (Fig. 9), whereas Microcodium rosettes are very rarely preserved. The non-luminescent cores of these grains are usually surrounded by a characteristic bright orange luminescent zone (Fig. 9).

In the uppermost part of the LC section atypical sediments with a honeycomb structure occur (Figs. 9A, B). They consist of thin calcite sheets, most likely calcite rafts, embedded in dull luminescent clotted micrite and microsparite forming bridges up to $1 \mathrm{~mm}$ thick separating rounded vugs (alveolas) and channels (i.e., atypical alveolar septal structure). The pores are usually surrounded by a very thin fringe of micrite or microsparite followed by fine-grained sparite, while the interior is filled with relatively pure, coarse-grained, isometric mosaic sparite. Some voids are completely filled with medium-orange luminescent brownish (in transmitted light) micrite (with or without grains related to calcified root cells). Some cements in the voids emit a whole spectrum of luminescent zones of different intensity and colour, reminiscent of zones in cements that locally fill secondary pores in reddish clotted micrites (see above; Figs. 7H, I). Particularly in the brownish micrite (in transmitted light), where grains related to calcified root cells are common, tiny branched channels resembling rhizoliths also occur.

In the upper parts of the cave section, pedogenic peloids are formed from brownish sediment containing grains related to calcified root cells (Figs. 9C, D). Again, some of the channels resemble rhizoliths. Contemporaneous with the intergranular pores, the rhizoliths were filled with microsparite, with some still poorly preserved fibrous texture.

In addition to the sedimentary structures already mentioned, parallel laminations also occur in the LC section. Laminas are the result of alternating deposition of 
grains of different sizes, periodic deposition of coarsergrained allochems within a fine-grained sediment, and occasional precipitation of calcite rafts. The lamina bases are erosional in some cases. Locally, fissures filled with the overlying cave sediments or sparite cements cut through the reddish cave sediment. As discussed previously, secondary pores occur primarily in the upper part of the cave section, most commonly in the pedogenically altered dark brownish-grey sediment.

\section{Isotopes}

The $\delta^{13} \mathrm{C}$ values of the sediments associated with the $\mathrm{LC}$ range from -10.12 to $-5.54 \%$ and the $\delta^{18} \mathrm{O}$ values range from -6.09 to $-5.30 \%$ (Fig. 4). Both $\delta^{13} \mathrm{C}$ and $\delta^{18} \mathrm{O}$ values are highest in the sediments of the lower part of the cave section, where no allochems or features directly related to pedogenic processes occur. Towards the top, along the section, the values gradually become lower and lower, coinciding with the increasing amount of soil-derived grains in the sediments and the intensity of their pedogenic modifications. The uniform sample of calcite rafts and matrix micrite shows quite low values of both $\delta^{13} \mathrm{C}$ $\left(-7.98 \%\right.$ ) and $\delta^{18} \mathrm{O}(-6.03 \%$ ) (Fig. 4), similar to the composition of cements from cavities in "honeycomb" structure $\left(\delta^{13} \mathrm{C}=-7.39 \%\right.$ and $\delta^{18} \mathrm{O}=-6.06 \%$ ) (Fig. 4$)$.

\section{Speleothems}

The speleothems are much less common then the reddish micritic cave sediments. Among them flowstones and the calcite rafts already described occur, while only a single small stalactite was found as a breccia clast. It should be noted, however, that the flowstone, although otherwise
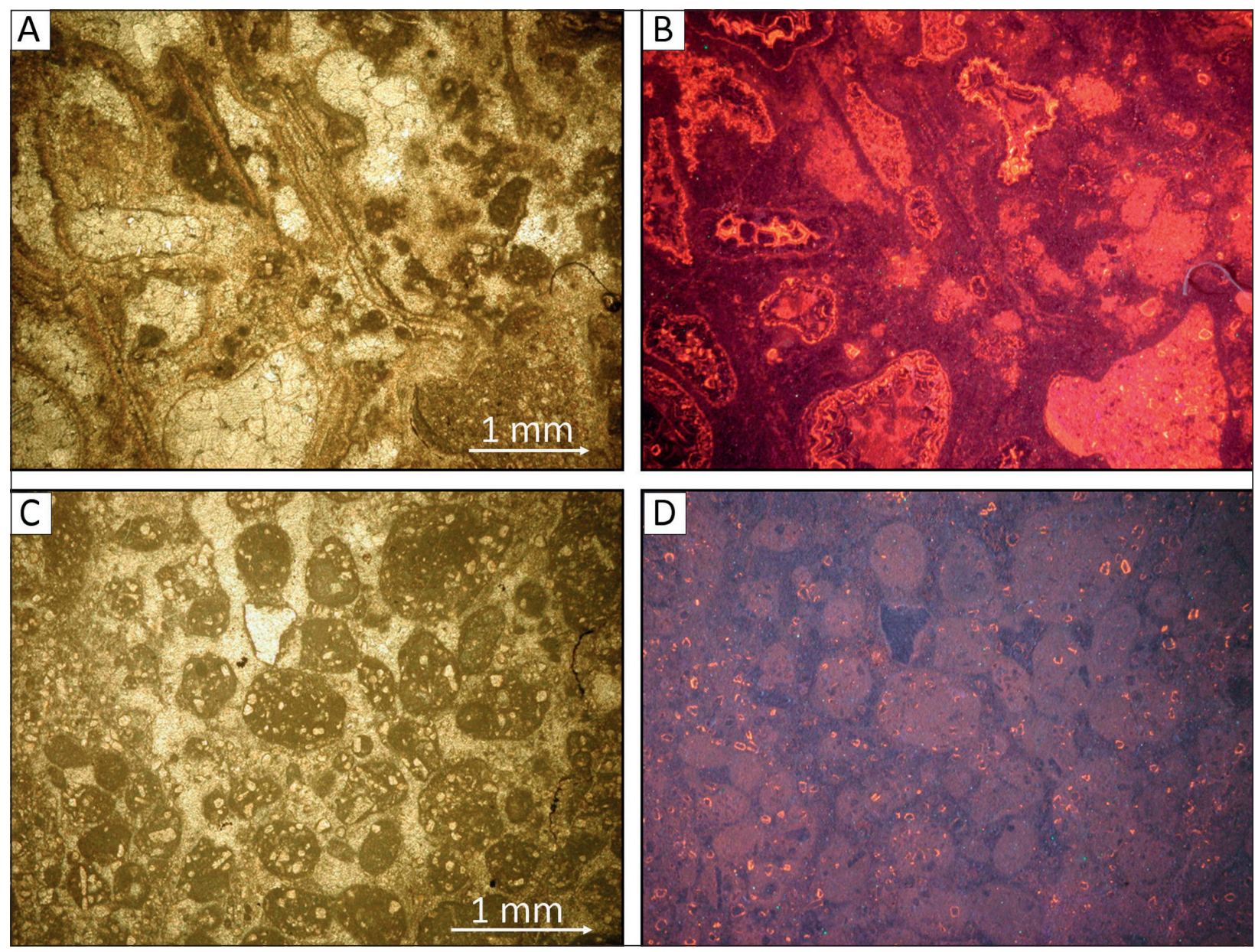

Fig. 9: Duplicated photomicrographs of the upper, pedogenically altered part of the LC section taken in transmitted light and cathodoluminescent light. A, B) A "honeycomb-like" structure of micritic to microsparitic bridges is reminiscent of an atypical alveolar septal structure. Rounded voids (alveolas) defined by the bridges (septa) are surrounded by a micritic or microsparitic lamina and filled with micrites containing calcified root cells, or isometric mosaic sparites, with characteristic zoned luminescence. $C, D$ ) "In-situ" pedogenic peloids that have developed in brownish pedogenic(?) micrite that contains grains of calcified root cells (with medium orange luminescent fringe) and grains of disaggregated calcite rafts. The intergranular pores between the peloids were most likely formed by rhizo- or some other bioturbation. It is also possible that the peloids themselves fill larger burrows formed in the pedogenically related micrite. 
found in the LC horizon, was never observed in direct contact with the sediments of the main cave section. Thus, there is a possibility that at least some flowstones are not associated with the LC depositional section.

White flowstones occur mainly in the lower part of the side channels of the LC, where they alternate with reddish-brown fine-grained cave sediments (Fig. 10A). They may also fill corrosion-widened joints, where they usually predominate over the other deposits (Fig. 10B). Flowstones are often corroded and disaggregated into individual crystals of silt- and sand-size. Such crystal grains were subsequently transported over shorter distances and deposited as grains within the reddish silty to sandy laminas that alternate with or overlie the flowstone (Fig. 10C). Especially near the paleokarst surface, secondary cavities, filled with various sediments of pedogenic origin, were commonly formed within the flowstones.

Flowstone layers, that rarely exceed $10 \mathrm{~cm}$ in thickness, generally consist of thick laminated accumulations of columnar calcite crystals that generally grow perpendicular to the substrate (Fig. 10B). The internal lamination is related to interruptions in flowstone growth combined with deposition of fine-grained reddish and greyish calcareous sediments. Where the sediment has been deposited only as a thin lamina, seam or impurity only, the flowstone crystals above such a layer are optically continuous with those below it. In such cases, the
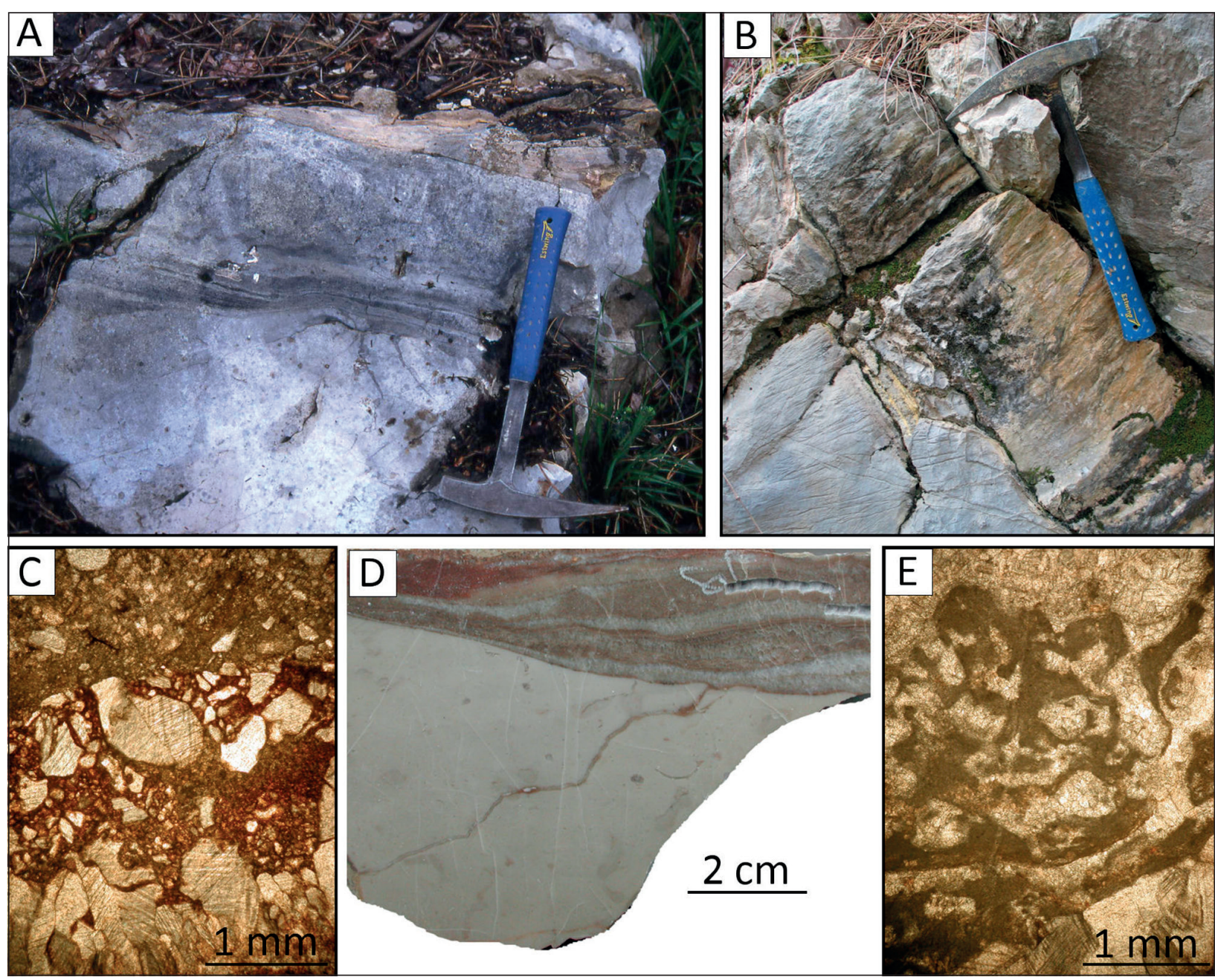

Fig. 10: Flowstone of the LC and side channels. A) The LC floor - contact of the cave deposit with the host rock. Flowstone and sediments alternate in the lower part. Note tiny flowstone (sparite?) filled cracks in cave floor (Photo: B. Otoničar). B) Massive flowstone fills widened fracture. Calcite crystals are more than $10 \mathrm{~cm}$ long (Photo: B. Otoničar). C) Heavily corroded flowstone in the lower part is overlain by a reddish-brown sediment with larger crystalline grains of disaggregated flowstone. A lamina of brown silt with crystalline debris of the disaggregated flowstone was deposited above the erosional contact. D) Lower contact of the cavity fill and host rock. In the lower part of the fill, laminas of light crystalline flowstone and brown micrite, arranged in an alveolar-septal texture, alternate. In the upper part, reddish and brownish cave sediment overlying the erosional surface (see Figs. 10E, C). E) Very irregular micrite lamina arranged in an alveolar-septal structure (see Fig. 10D). The micritic lamina is embedded in crystalline flowstone, which also fills the alveolas. 

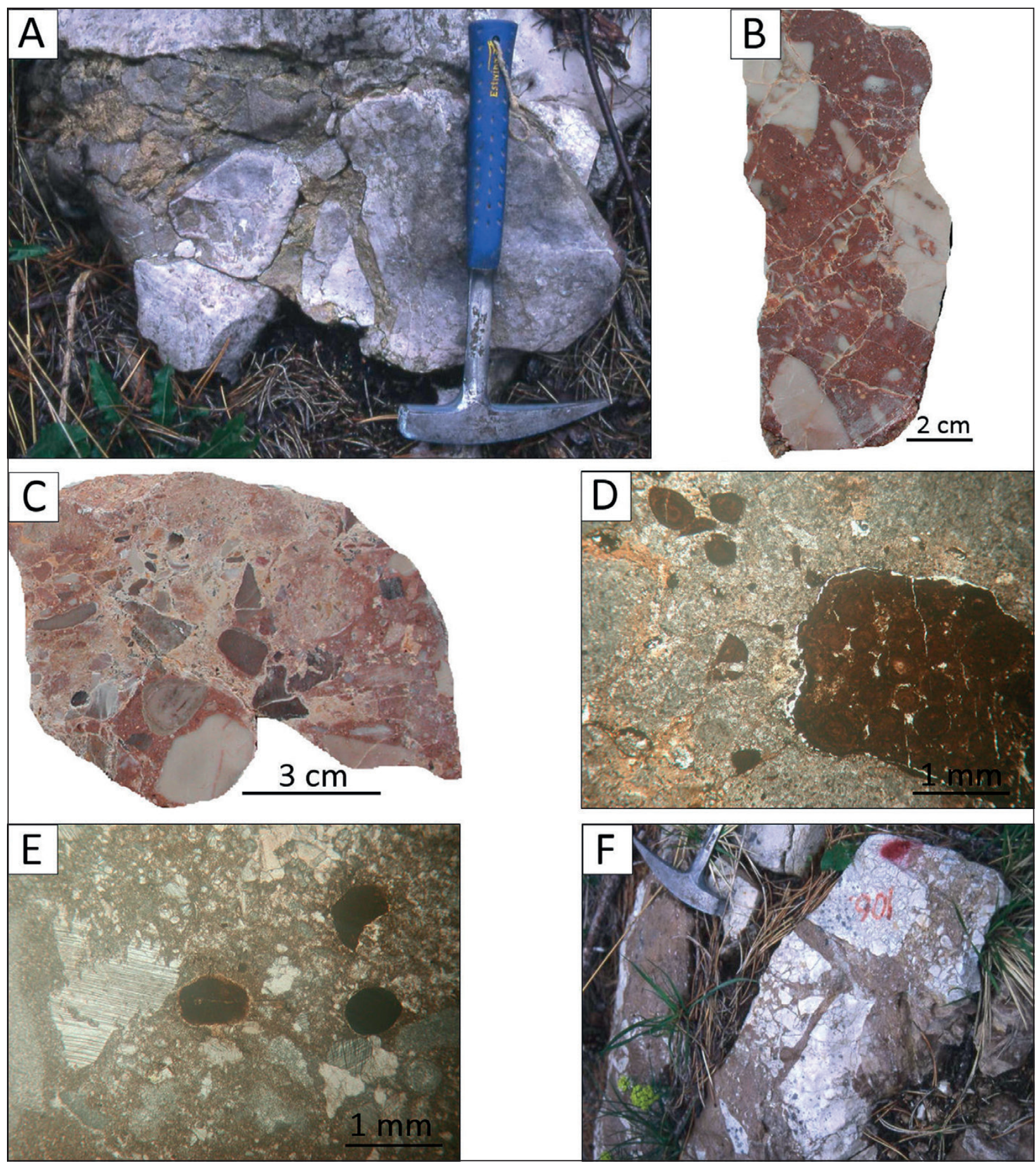

Fig. 11: Main characteristics of different types of breccias occurring in the horizon with the LC. A) Clast-supported mosaic to chaotic breccias underlying the LC ceiling. In addition to clasts of host rock of the immediate vicinity of the LC, cave sediments also occur as breccia clasts (Photo: B. Otoničar). B) An example of a "karstic" matrix-supported chaotic breccia, with characteristic reddish silty matrix (see Figure 11E). C) Fine-grained polymictic clast- to matrix-supported chaotic breccia. Note blackened clasts, probably derived from the paleokarst surface, and already resedimented (or in-situ formed) clasts composed of breccia. D) Breccia matrix from the upper part of the cave section. The matrix is a silty micrite of two generations (note cracking in the matrix of the first generation). Incomplete terrestrial ooids occur as individual clasts and as a major component of intraclasts. E) The matix of breccia from Figure 11B. Crystalline clusters of speleothems and cements, terrestrial ooids and grey micritic intraclasts of the host rock are common among the allochems. F) Matrix-rich mosaic breccia. The clasts were formed in-situ by secondary dissolution enlargement of joints, which were subsequently filled with reddish-brown sandy silt (Photo: B. Otoničar). 
individual columnar crystals may exceed $10 \mathrm{~cm}$ in length (Fig. 10B).

Locally in the lower parts of the LC, thin laminas of white and translucent crystalline flowstone alternate with about $2 \mathrm{~mm}$ thick brownish micritic layers arranged in alveolar septal structure (Figs. 10D, E). The micritic septa were primary built of locally still visible elongated calcite crystals of needle-fibre fabrice, while the alveolas are mostly filled with fine-grained isometric mosaic sparite and microsparite. The underside of the laminas with the alveolar septal structure is slightly undulated and follows the shape of the underlying crystal faces, while the upper surface is characteristically bushy and lumpy (Fig. 10E).

Only one preserved dark brown stalactite was found as breccia clast, which most likely cut pervasively into the host rock and cave deposits. The characteristic internal structure of the stalactite reveals a central channel filled with a fine-grained breccia matrix surrounded by concentric laminas of relatively fine-grained fibrous to columnar calcite crystals growing perpendicular to the axis of the channel. The crystals are fan-shaped in a direction from the central channel toward the edge of the stalactite. The crystal laminas are occasionally interrupted by tiny micritic laminas. Again, the individual crystals (domains?) below and above these lamellae are optically continuous and show uniform extinction.

\section{Isotopes}

The $\delta^{13} \mathrm{C}$ values of two samples of the crystalline flowstone range from -10.63 to $-7.29 \%$, and $\delta^{18} \mathrm{O}$ from -6.34 to $-5.80 \%$ (Fig. 4$)$. The $\delta^{13} \mathrm{C}\left(-8.89 \%\right.$ ) and $\delta^{18} \mathrm{O}$ values $\left(-6.11 \%\right.$ ) of the stalactite and the $\delta^{18} \mathrm{O}$ value of the flowstone lamina with alveolar-septal structure (-5.89 $\% 0)$ are also in this range, while its $\delta^{13} \mathrm{C}$ value is slightly lower $(-11.37 \%$ ) (Fig. 4). The isotopic composition of the calcite rafts is comparable to other speleothems $\left(\delta^{13} \mathrm{C}\right.$ values ranges from -8.70 to $-7.98 \%$, and $\delta^{18} \mathrm{O}$ from -6.03 to $-5.87 \%$ ) (Fig. 4 ).

\section{Breccia}

In the depositional succession of the LC a breccia is in direct contact with the other cave sediments only at the cave ceiling. However, in the upper about 25 metres below the paleokarst surface, patches of different types of breccia are very common and are not directly associated with the depositional sequence of the LC. Inhomogeneous, poorly sorted clast- (Fig. 11A) and matrix-supported breccias with a silty to sandy matrix occur in the upper part of the LC and in the aforementioned patches. In both breccia types, the clasts are derived from host rock and reddish cave fillings (Fig. 11A). They vary in size from the lower limit of the gravel to blocks several decimetres in size, with clasts from a few centimetres to about a decimetre in diameter being the most common (Figs. $11 \mathrm{~A}-\mathrm{C})$. The clasts vary in shape and have sharp to moderately rounded edges, whereas well-rounded clasts are rare. Grains of speleothems and cements, as well as intraclasts composed of terrestrial ooids, are rare (Fig. 11D), and because they are usually less than $2 \mathrm{~mm}$ in size, they can be considered part of the matrix. Among the larger clasts of speleothem, only the stalactite mentioned above was found. The matrix consists of a brownish (with reddish and yellowish hue in places), often clotted and silty micrite, in which grains of silt- and sand- size (i.e., disaggregated cements and speleothems, terrestrial ooids, and intraclasts of host rock and terrestrial oolites) are common (Fig. 11E).

Directly on the cave ceiling the fine-grained cave sediments and host rock are cut by widened cracks a few centimetres wide and up to a few decimetres long, filled with yellowish-brown sandy silt (Fig. 11A). It appears that a large proportion of breccias were formed in this way, although they vary in appearance depending on the density of the widened cracks and the nature of their filling, the lithology of the host rock/cave sediments involved, and the degree of recent weathering.

Breccias also occur near the lower part of the LC section, but their precise relationship to the cave sediments is unclear due to the patchy nature of the outcrops. Although the matrix in this part is slightly redder than in the breccia higher up in the geologic section (Figs. 11B, F), it is similar in composition (Fig. 11E) and thus younger than the reddish micritic cave deposits. In this case, the contact of the breccia with the host rock is distinctly cracked and the widened cracks are filled with sediment of similar composition to the breccia matrix. This part of the section also contains black pebbles (Fig. 11C) and individual terrestrial oncoids coated with a brown pedogenic micrite containing grains related to calcified root cells. Such allochems are otherwise characteristic of breccias filling vadose channels, cavities, and karst pockets just below the paleokarst surface. Cracks within some clasts were found to be filled with sparite and silty brownish micrite already before they became part of the breccia (Fig. 11B).

\section{Microturbidites of the side cavities}

The sediments of some decimetre-sized cavities occurring in the horizon with the LC or slightly above it show somewhat specific sedimentary structures (Fig. 12). Some of these cavities are filled with laminated sediments arranged in cycles. The single cycle is composed of a sequence of coarse-grained, graded calcareous sandstone up to a few centimetres thick, which grades upward into siltstone, silty micrite, and micrite (Fig. 12C). The sandstone is composed predominantly of crystalline calcite grains, whereas micritic intraclasts are less common. 

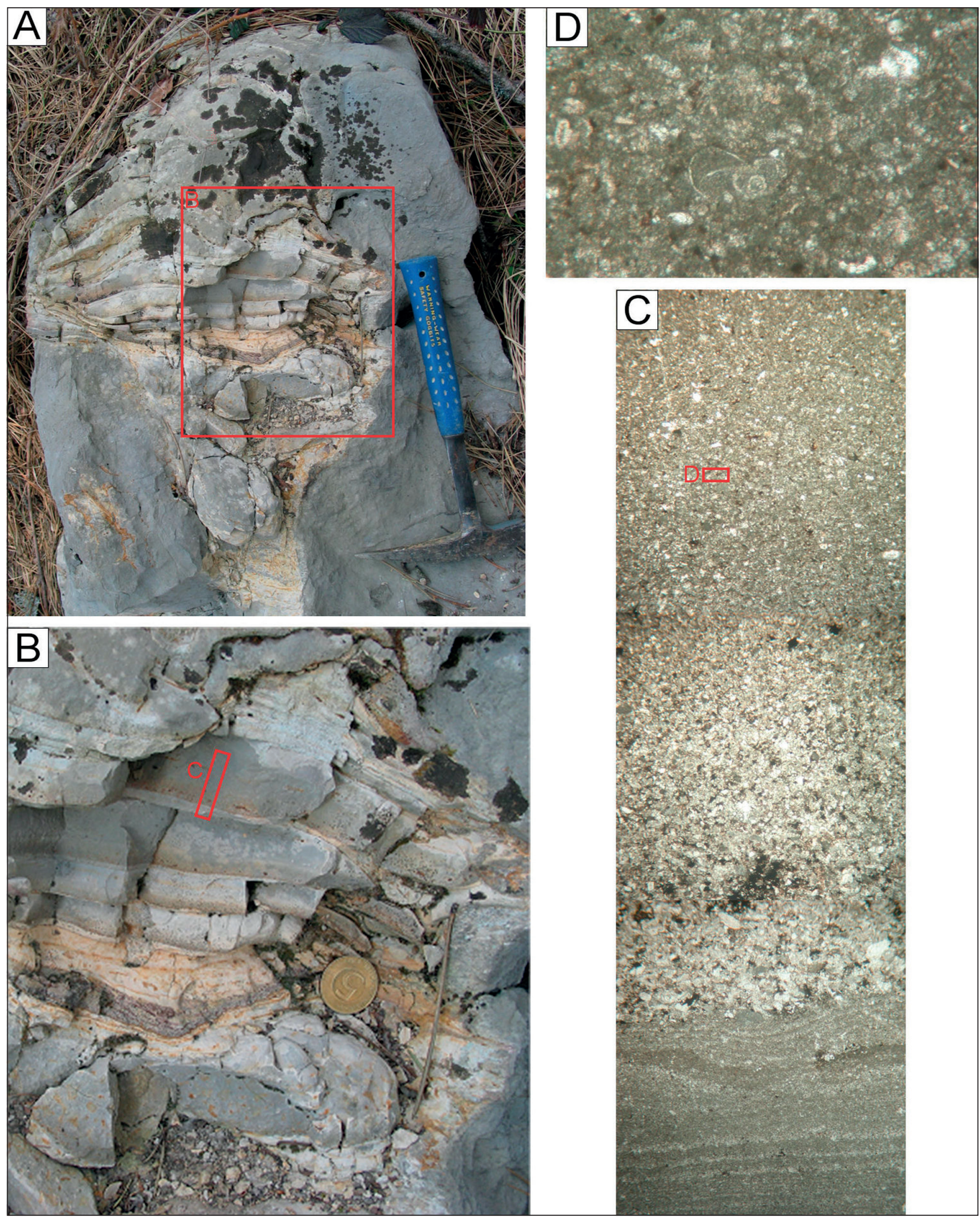

Fig. 12: Microturbidites. A, B) Cavity filled with cyclic sediments (Photo: B. Otoničar). C) The graded sedimentary sequence of each cycle begins with calcareous sandstone, followed by siltstone and silty mudstone (the top three quarters of the image), and ends with a very thinly laminated (silty) mudstone (bottom quarter of the image). D) Individual tiny foraminifera occur in the unlaminated silty mudstone, indicating the primary marine or brackish water origin of the sediment; i.e., "caymanite". The diameter of the coin in Figure $12 \mathrm{~B}$ is $26 \mathrm{~mm}$. The height of figure $12 \mathrm{C}$ is approximately $3 \mathrm{~cm}$. 
The origin of the micritic intraclasts is unclear, as they could be derived from the micritic part of the underlying cycles, the host rock, or the limestones that directly overlie the paleokarst surface. Important components of this part of the cycle are clusters of oxidised framboidal pyrite. In the micritic part of the cycles, individual small foraminifera (discorbids) occur (Fig. 12D) - a marine or brackish water fossil not otherwise found in any other cave-related sediment at the site studied, except as part of the host rock clasts. The cycles end with very thinly laminated micrites, where more than ten parallel, locally slightly undulating laminas may be concentrated within a millimetre of the sequence (Fig. 12C). The base of the next cycle is usually weakly eroded, although occasionally up to several cycles have been eroded (Fig. 12A; left side). One of the characteristics of the cyclic layers is also their lenticular shape. Upward, along the sedimentary sequence, the dip of the layers becomes steeper and steeper, so that the sedimentary body appears to have the shape of a cone or a fan (Fig. 12A). Locally, the laminas are slipped and plastically deformed. In some cavities, the deformations are expressed in the form of a tepee structure.

Semi-quantitative mineral analysis of a unified cycle yielded $88.3 \%$ calcite and $11.7 \%$ kaolinite.

\section{INTREPRETATION OF THE CAVE SEDIMENTS}

\section{FINE-GRAINED INTERNAL SEDIMENTS}

Fine-grained calcareous sediments mainly of mud- to silt-size are quantitatively the most important deposits of the cavities and caves of all three horizons considered. However, they differ between the horizons in colour, grain size and appearance, as well as in the type of coarser grains and isotopic composition.

In contrast to the micrites of the lower two horizons, the sediments of the LC are much more extensive and less homogeneous along the cave section and contain coarser-grained crystalline grains that are scattered unevenly throughout the section. From the bottom of the section upward, the increasing amount of surface-derived pedogenic silty to sandy particles (i.e., calcified root cells or Microcodium grains) and the rate of pedogenic alteration, as well as decreasing $\delta^{13} \mathrm{C}$ and $\delta^{18} \mathrm{O}$ values, indicate a gradually increasing connection with the paleokarstic surface or vadose zone. A more open connection with the paleokarstic surface is also documented in the centimetre- and decimetre-sized cavities of the second horizon, where some remaining voids above the geopetally deposited micrite and sparite fringe have also received at least some material from the paleokarstic surface (i.e., kaolinite, grains related to calcified root cells...).

To better understand the depositional environment of the fine-grained sediment and its origin, calcite rafts, which alternate with micrite and are more diagnostic cave deposits than fine-grained micrite, will be considered first. Calcite rafts, a thin, flat, microcrystalline calcite speleothem with planar upper and serrated lower surfaces that require the air-water interface for precipitation, are typically deposited in underground ponds or in the upper part of extensive fresh/brackish water lenses (see Hill \& Forti 1997; Csoma et al. 2006; van Hengstum et al. 2011; Kovacs 2017). Due to surface tension (Hill \& Forti 1997) and with the help of gas bubbles (Viehmann et al. 1997), precipitated rafts can be kept on the water surface until they grow enough to sink due to weight, occasional turbulence of the water (e.g., droplets, tropical storms) (van Hengstum et al. 2011; Kovacs 2017) or the pools dry out (Viehmann et al. 1997). By sinking to the bottom of pools, they are often excluded from the range of active crystal growth (Jones 1989) and accumulate much like dead leaves (Fig. 8). Because rafts form at the calm water surface where maximum $\mathrm{CO}_{2}$ loss occurs through degassing, which is particularly efficient when air circulation is obtained through multiple inlets (e.g., Yucatan cenotes) (van Hengstum et al. 2011; Kovacs 2017), similar conditions would also be expected in the LC during sedimentation of both rafts and fine-grained sediments. Precipitation, cementation, and dissolution of the rafts could have occurred in virtually the same environment (i.e., freshwater/brackishwater lens) due to dissolution at the halocline and precipitation of the rafts due to $\mathrm{CO}_{2}$ degassing at the water table (Thomas 1999). In our case, calcite rafts alternating with fine-grained, reddish sediments were probably more abundant than they appear, but were disaggregated during subsidence and subsequent depositional and diagenetic processes at the basin floor. The depleted $\delta^{13} \mathrm{C}$ and $\delta^{18} \mathrm{O}$ values indicate a large proportion of meteoric water and soil-derived $\mathrm{CO}_{2}$ in the water solution from which the rafts were precipitated, but $\delta^{13} \mathrm{C}$ values are higher compared to flowstones. This may be the result of more efficient degassing of lighter isotopes (Lohmann 1988), a different source and isotopic composition of the water [e.g., presence of marine derived organic matter (van Hengstum et al. 2011)], a relatively low water-to-rock ratio, and/or physical mixing of rafts and "interraft" deposits with slightly higher $\delta^{13} \mathrm{C}$ values (Fig. 4).

In the LC section, the increasing amount of grains associated with carbonate pedogenesis indicates that at least some of the fine-grained sediments are derived from the paleokarst surface and associated carbonate soil. Freshly precipitated or formed dense brownish micrite (under transmitted light) and needle fibre calcite, as well as recrystallized host rock, carbonate soil material, and the host rock intraclast, which have often been docu- 
mented directly beneath the paleokarst surface, are generally so fragile that they can easily be washed into the subsurface cavities during heavy rains. This scenario is also consistent with the very low $\delta^{13} \mathrm{C}$ and $\delta^{18} \mathrm{O}$ values of both the "pedogenic" deposits on the paleokarst surface and the fine-grained cave deposits. Moderately decreasing $\delta^{13} \mathrm{C}$ and $\delta^{18} \mathrm{O}$ values towards the upper part of the cave section may be the result of an increasing amount of pedogenic particles and subsequent pedogenic alteration of sediments in the upper part of the cave section. However, it should be noted that lacustrine and palustrine sediments directly overlying the paleokarst surface - and which were also adjacent to the subaerially exposed area (see Otoničar 2007, 2008) - also have very low $\delta^{13} \mathrm{C}$ and $\delta^{18} \mathrm{O}$ values (i.e., fresh or very dilute brackish ponds or lagoons). Consistent with the considerable amount of fine-grained sediment in the caves, transgressive lacustrine or palustrine sediments might well be plausible additional candidates for the source material, washed into the phreatic cavities and caves via vadose channels and fissures during tropical storms (see Jones 1992; van Hengstum et al. 2019). However, at a certain time, the source area should be close enough for storm surges to transport material to the potential entrances, as well as permeability high enough and hydrologic conditions appropriate for finer-grained suspended material to reach up to $75 \mathrm{~m}$ below the surface (assuming that most of the micrite within the caves of all three horizons discussed is of similar origin). Although the first transgressive deposits overlying the paleokarstic surface contain virtually no allochems and only sparse fossils, at least some of them would be expected to be preserved within the cave micrite if these were the source material (see discussion of microturbidites below).

Among internal (i.e., autochthonous) sources of fine-grained sediments, in-situ abiotic precipitation of micrite from supersaturated solution seems unlikely, as it requires exceptionally high numbers of pre-existing nuclei, high supersaturation, and/or the presence of organic compounds, a requirement that is rarely achieved even in seawater with a saturation index far exceeding that of cave waters (Frisia 2015). Smaller amounts of micrite production primarily with microbial intervention are possible (Jones 1989, 2010; Jones \& Kahle 1995), but are not quantitatively sufficient for significant micrite deposition. Smaller amounts of micrite may have precipitated directly from the cave pool water only around the calcite rafts (i.e., micrite - spar calcite rafts) (Figs. 8A-D) and in the interraft cavities (see Jones 1989). It is possible that a slightly larger amount of micrite may be provided by destructive bio-influenced erosion (e.g., boring, dissolution) (see Jones 1989, 2010) and condensation-corrosion processes (see Palmer 2007; Zupan-Hajna 2014; Frisia
2015), but it is very difficult to detect such sources if the micrite is already resedimented at a secondary site. It should be noted, however, that the bio-destructive processes attack and destroy calcite crystals lining nearsurface cavities or, at best, calcareous substrates in the twilight zone (Jones 2010). Furthermore, condensationcorrosion should be ruled out as the source of most of the micrite discussed, as micrite produced in this way would have much higher $\delta^{13} \mathrm{C}$ and $\delta^{18} \mathrm{O}$ values (see White et al., 2021). It is also unlikely that significant condensation-corrosion occurs inside caves (e.g., in cavities of the lower two horizons) where temperatures are stable and close to the mean annual external temperatures of the region, especially if external temperatures are also relatively constant and the climate is humid (i.e., in (sub) tropical regions) (Tarhule-Lips \& Ford 1998).

The mud-supported facies of the cave/cavities wallrock is commonly neomorphically altered or recrystallized into microsparite, suggesting alteration before or shortly after deposition of the fine-grained sediments. Similar composition and granulation of the cave sediments and the micritic and microsparitic host rock, as well as scattered sand-grained crystalline grains within the finer-grained cave sediment and comparable isotopic composition of the cave sediment and the neomorphosed portions of the host rock, suggest that most of the fine-grained cave sediment may have been eroded from the weathered cave-walls. In flooded caves formed in eogenetic carbonate rocks of the subtropical Yucatan and Florida peninsulas and the Mediterranean island of Majorca, the cave walls often consist of soft weathered host rock, especially in the recent mixing zone (Smart et al. 2006; Fornós et al. 2009). The clay, silt and fine sand particles can be detached even by diver's exhaust bubbles forming a fine 'gritty snow' (Smart et al. 2006) or 'rain of sandy sediment' (Fornós et al. 2009) deposited as abundant white and reddish-yellow fine-grained sediment with scattered coarser-grained, irregular fretted gravels. In the coastal karst caves of Majorca (Csoma et al. 2006; Fornós et al. 2009) and especially in the Yucatan Quintana Roo-type caves (Smart et al. 2006; van Hengstum et al. 2011; Kovacs 2017), deposits of the fine-grained eroded weathered wall-rock material and calcite rafts often occur in close proximity to each other. As mentioned above, calcite rafts can also form at the water surface even of the same pool where dissolution and hence cave wall weathering occur simultaneously in the underlying mixing zone (Thomas 1999). It is possible to some degree that the deposition of calcite rafts and fine-grained sediments alternate in response to storms and heavy rain events. On the one hand, heavy rain events can increase the total salinity of the meteoric water lens as a result of mixing with marine water mass, while on the other hand 
they dilute the supersaturated upper meteoric water mass and hinder the precipitation of rafts for days and weeks after the event (Kovacs 2017). It can be hypothesized that under wet conditions (i.e., increased hurricane intensity), recharge through vadose channels would not only flush material from the karst surface and vadose zone into the phreatic caves, but water turbulence would also cause calcite rafts to sink and erode weathered cave wall debris, depositing it on the pool floor. Increased limestone dissolution and outgassing of $\mathrm{CO}_{2}$ from the water surface returned supersaturated conditions to the surface basin water within days or weeks of rain events, and when the water also stagnated, precipitation of calcite rafts was restored (see Kovacs 2017).

Bands of dark brownish grey sediments in the uppermost part of the LC (Fig. 6C) with the atypical alveolar septal structure and peloids (Fig. 9) of brownish micrite represent pedogenically modified cave sediment. The septa of the alveolar septal structure as well as the interpeloidal pores were originally formed by locally preserved needle fibre calcite (NFC), indicating precipitation in the soil with fungal activity (i.e., rhizomorphs) (Verrecchia 2011). (Figs. 9C, D) (see also below). Peloids were formed by textural inversion from micritic parent soil material in which moist and dry conditions alternate (see Wright \& Tucker 1991). It is possible that both the alveolar septal structure and the peloids were in some way associated with a root system of higher plants, as evidenced by grains related to calcified root cells embedded in parent soil material of the two features described (Fig. 9). The roots most likely penetrated through the vadose zone into the often moist cave sediment to form a "speleosoil".

\section{SPELEOTHEMS}

Flowstones, precipitated with $\mathrm{CO}_{2}$ degassing from thin films of water seeping over inclined cave floors and walls, are one of the most characteristic indicators of the vadose cave environment. While different calcite fabrics of speleothems can be attributed to changes in supersaturation, drip/flow rate or input of detrital/organic compounds, as well as postdepositional changes during diagenesis (see Frisia 2015), the alternating deposition of crystalline flowstone bundles and reddish-brown sediments, interrupted by periods of dissolution (and bioerosion?) and mechanical erosion (Figs. 10C, D) may also indicate changes in catchment area, supply routes, and/ or recharge intensities, and thus seasonal (wet vs. dry) or longer-term climatic changes, as well as evolution of the karst system itself (e.g, denudation, soil maturation, and diagenetic (karstification) evolution of the karst system). The distinct dark brown colour of the stalactite indicates the presence of organic matter inclusions (Hill \& Forti 1997).
Individual micritic laminas arranged in alveolar septal structures with locally preserved NFC intercalating with crystalline calcite and reddish-brown micrite resemble structures of pedogenically modified carbonates (see Wright 1986, Loisy et al. 1999; Košir et al. 2005). Such features result from microbial adhesion of calcite fibres, bioturbation in the soil, or water cohesion percolating along pore walls (Košir et al. 2005). In soil profiles, NFC seems to be mainly related to fungal activity, as it is always associated with fungal filaments (rhizomorphs) (Verrecchia 2011). Callot et al. (1985) found that simple rod-like calcite fibres are formed by biologically induced mineralization in fungal hyphae. Poorly preserved NFC in the flowstone discussed can be attributed to diagenetic epitaxial overgrowth, a common feature within soil pores (Verrecchia \& Verrecchia 1994; Verrecchia 2011). Although NFC is a common form of $\mathrm{CaCO}_{3}$ in vadose environments, particularly in soils and pedogenic calcretes, such forms of carbonate crystals can also be formed by inorganic precipitation from supersaturated solutions (Borsato et al. 2000). Similarly shaped clusters of fibrous calcite can form in cave environments (moon milk, cave cotton), where microorganisms probably have no direct influence on their precipitation (Borsato et al. 2000). Although needle-fibre calcite can be precipitated under very different climatic conditions (Verrecchia \& Verrecchia 1994), the most suitable environments for the preservation of such forms are pedogenic horizons of warm, especially arid climates (Wright \& Tucker 1991). In summary, the recrystallized needle fibre calcite arranged in alveolar septal structure was most likely formed in the vadose zone by biologically induced processes.

The carbon and oxygen isotopic compositions of the flowstones reflect a dominance of meteoric water and $\mathrm{CO}_{2}$ from soil colonised with $\mathrm{C} 3$ carbon-fixing plants in the water solution from which they were precipitated. Similar to calcite flowstones, a slightly higher $\delta^{13} \mathrm{C}$ value of stalactite can be attributed to a high $\mathrm{CO}_{2}$ degassing rate.

It can be concluded that the relatively small amount of vadose speleothems indicates a limited time and/or a rather dry climate for most of the time that the LC and associated cavities were exposed to the vadose zone.

\section{BRECCIAS}

According to the classification of Loucks (1999), the clast-supported breccias with different clasts and the matrix-supported breccias with the host rock clasts can be described as chaotic (Figs. 11A-C), whereas those at the contacts with the host rock are mosaic (Fig. 11F) and crackle breccias. For the most part, the breccias cannot be directly associated with the processes involved in the formation, modification, and disintegra- 
tion (i.e., collapse) of caves. In the upper part of the LC section, brecciation is commonly apparent and was formed mainly by intertwined vadose channels or widened fissures filled with yellowish-brown "pedogenic" sediments that mostly penetrate to the upper part of the LC fillings (Fig. 11A). Regarding the composition of smaller clasts (e.g., pedogenic ooids) and matrix (i.e., brownish pedogenic micrite with grains related to calcified root cells), breccias occurring just below the LC are also assigned to the vadose and pedogenic zone (Figs. $11 \mathrm{C}, \mathrm{D})$. They most likely represent vadose and/or relict phreatic channels located in the vadose zone and subsequently filled with material derived from the paleokarst surface. It is possible that the lower parts of these cavities were first filled with the red cave sediments. Chaotic breccias of this type are expected in the entrance parts of caves where subsurface phreatic channels are open directly to the surface through vadose channels (i.e., shafts, pockets, widened joints, root casts etc.). It is likely that the surface material was redeposited into the underground caves and cavities during extreme weather conditions (e.g., heavy rains, tropical storms).

The formation of mosaic breccias (Fig. 11F) is related to the dissolution of cracks on the walls of pre-existing vadose and/or phreatic channels and caves, followed by the deposition of reddish sediment containing a considerable amount of pedogenic particles. Also in this case, some clasts are apparent as they are still attached to the host rock.

\section{MICROTURBIDITES}

The described succession of cave sediments is arranged in well-expressed microsequences (Fig. 12), reminiscent of Bauma sequences, deposited from low-density gravitational turbidity currents. Similar to what often occurs in large-scale turbidites, not all five layers of the ideal Bauma sequence occur, but only the first three: A- graded coarse- to fine-grained sandstone, B- planar-laminated fine-grained sandstone to siltstone, and C- ripple-laminated siltstone to mudstone. Similar to larger turbidites, the base of the A layer is sometimes erosional and cuts into the underlying sequence(s).

Each sequence represents a single subaqueous depositional event of waning flow as turbidity currents move downslope (see Jones 1992). Laminated, graded sediments, which often forming cones or fans, were deposited in ponded water. The supply of sediments, from the surface or side channels of the cave, was localized and periodic. How well pronounced the cones will be and what the internal structure of the sediments will be depends on the sediment granulation, the position and shape of the supply channel (e.g., ceiling or sidewall channel, re-sedimentation in the same room...), the amount of water in the sediment, and the shape of the cavity or pool in which the sediment is deposited (see Osborne 2008). In our case, a combination of different depositional mechanisms took place, while erosion also occurred in the lower part of the individual cycle (Fig. 12). The filling of the erosional channel is not well defined, but in general the granulation, which resembles the overlying layers, indicates similar source and turbidite current characteristics, but with different depositional base (narrow vs. wide channel). Overlying cyclic sedimentation of graded lenticular laminas with progressively steeper slopes may be attributed to a localized supply point of water that was relatively heavily loaded with sediment. When the inclination angle of the laminas exceeded the critical point, they became plastically deformed and slipped. Marine or brackish water foraminifera and the presence of pyrite indicate a possible, at least a slightly, salty environment, not only the source environment but also the depositional environment within the cavity, while certain amount of kaolinite indicates some relation with the paleokarst surface or vadose channels. Foraminifera with other sediments may have been re-sedimented from adjacent palustrine environments or from the cave itself, as live foraminifera have been reported from anchialine and marine caves of Yucatan, Bermuda, and the Bahamas (van Hengstum et al. 2019). Pyrite may indicate processes occurring at the redox boundary, similar to those described above (see Stoessell 1992; Whitaker \& Smart 1998; Baceta et al. 2007), or the subsequent presence of seawater in the system (i.e., marine hydromorphism) (Wright et al. 1997).

In summary, each sequence may represent a sudden but periodic event in which water laden with sediment from the palustrine environment and the paleokarst surface adjacent to the cave entrance or from the cave itself suddenly lost its energy as it entered the pond and deposited the sediment on the cave floor. The periodicity may be attributed to heavy rain or storm events that occur periodically in (sub)tropical regions. Similar sediments were described by Jones (1992) from Miocene cave fillings of the Cayman Islands and Korpás et al. (1999) from the thermal karst of Buda Hills in Hungary. Osborne (2008) has reviewed cave turbidites from different geological periods around the world, loaded with different parent material and deposited in different cave environments. 


\section{DISCUSSION}

The studied carbonate section, ending with a regional unconformity, represents an ancient karst system formed when a significant area of a young, diagenetically immature, shallow-marine carbonate platform was exposed to the land surface and meteoric water (Otoničar 2006, 2007, 2008, 2016). A vadose and phreatic meteoric hydrogeological system (i.e., a freshwater lens) formed beneath the paleokarst surface with an intermediate mixed freshwater-marine water (brackish) hydrological zone at the contact with the underlying seawater. Depending on the gradually changing hydrogeochemical and geological conditions, specific diagenetic, karstic and depositional processes took place in each of the aforementioned hydrogeological zones, leaving their traces in specific diagenetic alteration of the host rock and dissolution features with associated internal deposits. From the resulting diagenetic and depositional features, it is possible to infer an evolution of hydrogeological zones or a hydrogeological (karst) system as a whole, and hence relative sea-level changes.

The research results indicate that the effects of karstification intensified towards the paleokarst surface and, accordingly, the depositional and isotopic characteristics of the internal sediments also gradually changed, both from smaller vugs and larger cavities/caves. Although the host rocks do not show significant neomorphic changes in translucent and cathodoluminescent light, except at the contacts with pedogenically related deposits at the paleokarst surface/vadose channels and some phreatic cavities, the diagenetic alterations of the primary marine deposits are reflected in their $\delta^{13} \mathrm{C}$ and $\delta^{18} \mathrm{O}$ values, which systematically decrease towards the paleokarst surface. Similar trends in isotopic composition also occur in the cements and internal sediments of the smaller vugs and in the LC depositional section. As suggested for the Florida aquifer (see Cander 1995), the isotopic composition and other diagenetic characteristics of the host rock, the smaller vugs and the larger cavities/caves indicate that at least two, if not three, diagenetic systems coexisted within the aquifer of the paleokarst discussed or the site of most efficient diagenesis shifted from one to the other over time: 1) a less efficient matrix system in the host rock with varying but relatively low rates of diagenetic alterations, 2) a network of smaller vugs with intermittent diagenetic efficiency, and 3) a conduit network with significant limestone dissolution, precipitation, and sedimentation (Fig. 4). Whether the network of smaller vugs and the conduit network are part of the same diagenetic system is difficult to answer. However, each of them has some diagenetic features of its own.

When the eogenetic carbonate platform was ini- tially exposed to the meteoric diagenetic zone during the major subaerial exposure period, the carbonate sediments were diagenetically more or less immature, with some exceptions formed during minor events when the carbonate sediments were exposed to the land surface or seafloor (e.g., at the first and composite sequence boundary). Indeed, the geochemical composition and diagenetic alteration of the host rock limestone exposed to meteoric water is generally tied to the initial, albeit brief, sea-level fall event rather than to a later, perhaps larger amplitude, sea-level fall (Melim et al. 2004). Although host sediment diagenesis is presumably rock-buffered and dominated during the short or early phases of subaerial exposure events, before conduit flow was established and diagenesis gradually focused out the host sediment (Cander 1995), it was long or efficient enough that host limestone did not retain marine geochemical composition but showed significant meteoric water influence and a relatively high meteoric water/rock ratio during diagenetic stabilisation. Thus, meteoric groundwater caused an almost complete resetting of oxygen isotopic composition, often with a high resetting of carbon isotopic composition as well, with significant amounts of carbon derived from meteoric water or soil $\mathrm{CO}_{2}$.

Synchronous with maturation of the diagenetic system (i.e., mineral stabilisation, cementation, neomorphic alteration), secondary porosity increases, although the processes of dissolution and precipitation do not involve long transports of chemical compounds (Morse \& Mackenzie 1990). Although the percentage of porosity is maintained during the initial stages of meteoric diagenesis (Wright 2002), permeability, which depends primarily on the nature of the matrix, decreases, particularly if the matrix is mud-dominated (Budd 2002). At least in the early stages of karst aquifer development in the young, subaerially exposed carbonate platforms, mixing of freshwater and saltwater is limited at the lower boundaries of the freshwater lenses due to diffuse flow. In meteoric zones, the problem appears to be primarily the large length and surface area of the pores relative to the discharge (i.e., relatively low water/rock ratio), which would prevent mass equilibrium-induced dissolution (Palmer 1995). It is likely that extensive mixing of water and karstification would be difficult to achieve in such zones without sections of high primary permeability that would allow more intense flow both in the freshwater lens area and below (Dreybrodt 2004, personal communication). Similar to reports from the Great Bahama Bank subsurface (Beach 1995), bioturbation burrows, which are particularly common in the second horizon, may also represent sites of increased primary permeabil- 
ity at the site discussed. In addition, the preferential direction of water flow and hence accelerated dissolution at these sites may also occur over horizons that were indurated prior to major subaerial exposure (see Beach 1995; Mylroie \& Carew 1995a; Whitaker \& Smart 1997) and roughly coincide with the lower part of the first and second cavity horizons (Fig. 4). Although extensive fracture porosity is difficult to assess in young, still not completely indurated diagenetically immature carbonate deposits, it cannot be completely ruled out as an incipient pathway for water flow, especially considering that the uplift was tectonically induced (Otoničar 2007; Jež \& Otoničar 2018). In areas of recent carbonate platforms, fissure zones with high flow rates, pronounced mixing and influx of organic matter from the surface have a significant influence on diagenetic processes in intergranular aquifers (Whitaker \& Smart 1997). The strong tidal pumping of water along fissures accelerates water flow and mixing both in the fissures and pre-developed channels and in the adjacent intergranular aquifer, where the influence on diagenesis can be traced up to $200 \mathrm{~m}$ from the fissures in some places.

Once a more permeable incipient conduit system is established, diagenesis gradually shifts out of the host rock and focuses into the conduits (see Cander 1995). It is difficult, if not impossible, to determine the exact timing of the formation of the LC and smaller accompanying and underlying vugs and conduits, as different processes may occur simultaneously in different parts of the 'eogenetic freshwater lens' aquifer (see Morse \& Mackenzie 1990; Stoessel 1992; Whitaker \& Smart 1998; Thomas 1999). One of the most plausible scenarios is discussed below. The typical two-dimensional horizontal distribution of channels/chambers, the distinctly irregular shape of cave walls surrounded by numerous smaller vugs and channels, and also pendants, columns and shelves of host rock subdividing larger filled cave chambers (Fig. 5A) are characteristic of caves formed in the young, diagenetically immature carbonate rocks at the interface of freshwater and seawater of the tropical islands (e.g., Bahamas) (Vogel et al. 1990; Carew \& Mylroie 1994; Mylroie \& Carew 1995a, b) and extensive peninsulas representing uplifted carbonate platforms (e.g., Yucatan, Florida) (Smart et al. 2006; Kambesis \& Coke IV 2013). Although the limited insight into the actual arrangement of the cave passages and their extent prevents a more precise determination of the pattern and hence the origin of the caves, it is more likely that the associated karst aquifer is comparable to the aquifers of the extensive peninsulas than to the aquifers of the smaller tropical islands, mainly because of the size of the subaerially exposed areas and the associated extent of the aquifer, and partly with regard to the cave sediments. However, as pointed out by Smart et al.
(2006), there may be a continuum between flank margin and Quintana Roo -type caves determined by the magnitude of specific shoreline runoff. Considering the isochrones of the youngest strata underlying and the oldest strata overlying the paleokarst surface and the extent of stratigraphic gap over the area of SW Slovenia and Istria obtained from 36 geological sections (Otoničar 2007), there should also be a considerable inland catchment in the discussed paleokarst aquifer and an associated high specific discharge, producing high rates of mixing dissolution and extensive cave systems (see Otoničar \& Košir 2016). Moreover, the cave sediments and associated collapse breccias are so extensive in some places that, although not properly identified at the time, they were mapped as a separate lithological unit on the 1:100,000 scale geological map of Yugoslavia, which could be followed for kilometres (Magaš 1968; Otoničar 2008).

Given the geologic, hydrogeologic, and morphologic features and conditions described above, we hypothesise that the LC was formed in a coastal mixing zone where dissolution driven by mixing of fresh and saline water is more efficient due to greater net discharge of both waters (Smart et al. 2006). However, since the LC was formed at least 25 metres below the land surface - the ceiling should primarily be even thicker, but was reduced by denudation - and the dip of the slope towards the sea probably roughly matched the gently inclined slope of the depositional ramp system (if there was no significant movement along simultaneously active faults) (see below), then the LC was neither formed nor filled directly at the shore, but rather inland, at least several kilometres from the shore. Such a distance is consistent with the present situation in Yucatan, where major cave "belt" is stretching more than $10 \mathrm{~km}$ inland from the coast (see Thomas 1999; Smart et al. 2006; Kambesis \& Coke IV 2013). Regardless, the LC was subsequently uplifted into the vadose zone where flowstone was deposited in the lower part of the cave. At the same time, the meteoric phreatic and mixing zones also had to be moved downwards, where cavities of the lower horizons formed and perhaps some diagenetic alteration of the host rocks and sediments in the bioturbation pits took place, as these deposits would be exposed for the first time to the freshwater lens of the main paleokarstic period according to the scenario discussed. As the area under study represents a subaerially exposed part of a peripheral bulge surrounded by a synorogenic carbonate platform with a ramp topography (Otoničar 2007), a relative sea-level drop of only 10 metres would expose a belt of former palustrine environments at least 1 kilometre wide adjacent to the large karst island. Such sea-level drops are regularly documented as relatively thin, pedogenically altered or karstified horizons within the first few to tens of metres of the sequence overlying the main 
paleokarst surface. Accordingly, a dissolution site driven by mixing of fresh and salt water, and more efficient in coastal areas as noted above, would be displaced in this direction. A similar effect can also be achieved during standstills with depositional progradation of sediments towards the sea (Kambesis \& Coke IV 2013), but in this case the LC would remain inundated by freshwater. We should also be aware that once formed channels had an important influence on the hydrogeology and subsequent course of diagenesis and karstification in the aquifer (see Mylroie \& Carew, 1995a Smart et al. 2006; Kambesis \& Coke IV 2013), however these are details that are difficult to discern in the fossil record.

The LC was probably filled with freshwater or less likely dilute brackish water mainly with fine-grained sediments during subsequent reflooding. In view of the intercalated calcite rafts, which require a free water surface and effective degassing for precipitation, the cave was mostly inundated by the subsurface lake during deposition as the upper part of the phreatic zone or freshwater lens. It is possible that during this time some passages of the lower cave zones were partially filled with micrite. A well- ventilated cave and the associated effective degassing could be formed by several cave entrances formed by collapses of the cave ceiling and by the dissolving enlargement of the primary narrow but permeable passages, due to the long duration of subaerial exposure and the associated approach of the karst surface to the cave by denudation processes. This can also be seen in the provenance of the cave sediments, which gradually acquire more surface-related particles.

The horizon with oxidised disseminated pyrite and associated filled vugs and cavities of the second cavity horizon (Figs. 3A, C) may indicate a location of the mixing zone in certain time. Although iron oxides may be precipitated directly where upwelling anoxic saline groundwater mixes with the overlying oxygenated freshwater (see van Hengstum et al. 2019), it is more likely that the stains were formed by the oxidation of iron sulphides - still visible as oxidised disseminated pyrite in thin sections - formed in the mixing brackish-marine zone by the action of anaerobic sulphate-reducing bacteria (Whitaker \& Smart 1998). As the vadose zone became more permeable, organic material important to the above biochemical processes was able to percolate from the surface into the phreatic zone, where it was suspended due to changes in groundwater density (often in the upper and lower parts of the mixing zone) or accumulated at the bottom of cavities and over less permeable parts of the aquifer (e.g., over better cemented unconformities or micritic layers - see above) (see Whitaker \& Smart 1998). Oxidation of organic matter by sulphate reduction produces $\mathrm{H}_{2} \mathrm{~S}$, which diffuses towards the reduction-oxida- tion boundary where it is reoxidized to sulfuric acid. If dissolved iron is present in the solution, $\mathrm{H}_{2} \mathrm{~S}$ can react with it to form FeS, which eventually recrystallizes to pyrite (Palmer 2007). The reduction-oxidation interface, where the processes of bacterial aerobic oxidation of organic matter and re-oxidation of reduced sulphur species run simultaneously, is an important area of calcite dissolution and can also occur within freshwater lenses (Whitaker \& Smart 1998). The increase in $\mathrm{pH}$ in these reactions exceeds the increase in alkalinity that, under similar conditions, may be due to oxidation of organic matter by sulphate reduction, which otherwise accelerates precipitation of carbonates (Morse \& Mackenzie 1990; Stoessel 1992). It is possible that these processes led to precipitation of coarse-grained NL columnar to bladed fringing sparite, post-dating the oxidised pyrite mottles (Fig. 3A, C), within the vugs in the overlying freshwater lens just prior to the next major water table fall.

However, from the other side, diffusion of dissolved bicarbonate to the water table and degassing of $\mathrm{CO}_{2}$ into the cave atmosphere leads to precipitation of calcite rafts on the water table, which would simultaneously maintain water aggressiveness, dissolution of carbonates, and corresponding increase in $\mathrm{pCO}_{2}$ in the lower parts of the lens (i.e., in the mixing zone) (Thomas 1999).

Similar processes are described from paleokarst developed in Paleocene limestones of the western Pyrenees, where $\mathrm{Fe}$ oxides line the pore walls of a "Swiss cheese" horizon up to several meters wide, filled with red internal sediments, while Fe sulfide impregnations and disseminations occur in the underlying neomorphosed limestone (Baceta et al. 2007).

Vadose channels cutting through the LC sediments indicate that the next water table fall below the LC floor. As mentioned above, because the interviewing of the destructive and constructive diagenetic and karstic phenomena, it is difficult to say whether the lowermost cavity horizon was formed during this event or before, but certainly some remaining voids of the second horizon, as well as pedogenic modification of the LC sediments and breccia formation, most likely occurred during this phase. It is possible that some of the flowstones of widened fissures were also precipitated during this phase.

During the last phase of water table and associated sea level rise, just prior to transgression over the paleokarst surface, microturbidites were deposited during periodic extreme weather events when sediments from adjacent palustrine environments (fresh to brackish water lakes or lagoons) and the paleokarst surface were resedimented into the cavities. The isotopic composition of the dark gray mudstone directly overlying the paleokarst surface suggests deposition from a freshwater or highly dilute brackish water environment. 


\section{CONCLUSIONS}

The main results of the study of the paleokarst phreatic caves, cavities and vugs and the related internal deposits and host rock at Podgrad village in SW Slovenia have shown the following:

- The host rock was uplifted above sea level and exposed to meteoric water as diagenetically immature carbonate sediment, which subsequently underwent diagenetic alterations in the meteoric and freshwaterseawater mixing zone.

- Phreatic caves and cavities formed in three horizons, most likely reflecting different levels of the freshwater/ seawater mixing zone and associated freshwater lens. The site of most intense diagenesis has shifted from the matrix diagenetic system to the channel flow diagenetic system. In addition to the filled cavities and vugs of the second horizon, the belt of oxidised disseminated pyrite also indicates the location of the mixing zone at a certain time.

- Diagenetic alterations of primary shallow-marine host rock deposits are reflected in their $\delta^{13} \mathrm{C}$ and $\delta^{18} \mathrm{O}$ values. The $\delta^{13} \mathrm{C}$ values systematically decrease towards the paleokarst surface, while the $\delta^{18} \mathrm{O}$ values are rela- tively constant but much lower compared to the marine limestone (i.e. the meteoritic calcite line). Similar trends in isotopic composition also occur in the cements and internal sediments of the smaller vugs and within the LC depositional section.

- The most abundant fine-grained, reddish-coloured internal cave sediments are derived primarily from weathered wall rock and calcite rafts. Towards the paleokarst surface, the proportion of "pedogenic" particles increases in the cavities as well as within the LC depositional section. Calcite rafts indicate a free water surface and a well-ventilated cave achieved by multiple cave entrances.

- Given the characteristics of the LC and other cavities, their distribution, the internal deposits, particularly from the LC, the location of disseminated pyrite, and the distribution of vadose channels, it is suggested that the water table and associated freshwater lens fluctuated during the paleokarst period, as reflected in features associated with minor subaerial exposure events in the adjacent and overlying palustrine deposits.

\section{ACKNOWLEDGMENTS}

This study was supported by Programme P6-0119 (Karst Research) of the Slovenian Research Agency. The author thanks two reviewers for helpful comments that helped improve the article.

\section{REFERENCES}

Baceta, J.I., Wright, V.P, Beavington-Penney, S.J. \& V. Pujalte, 2007: Palaeohydrogeological control of palaeokarst macro-porosity genesis during a major sea-level lowstand: Danian of the Urbasa-Andia plateau, Navarra, North Spain.- Sedimentary Geology, 199, 3-4, 141-169. https://doi.org/10.1016/j. sedgeo.2007.01.024

Beach, D.K., 1995: Controls and effects of subaerial exposure on cementation and development of secondary porosity in the subsurface of Greath Bahama Bank.- In: Budd, D.A. et al. (eds.) Unconformities and porosity in carbonate strata. AAPG memoir, 63, American Association of Petrolium Geologists, pp. 1-33, Tulsa.

Borsato, A., Frisia, S., Jones, B. \& K. Van der Borg, 2000:
Calcite moonmilk: Crystal morphology and environment of formation in caves in the Italian Alps.Journal of Sedimentary Research, 70, 5, 1171-1182. https://doi.org/10.1306/032300701171

Bosak, P., Ford, D.C. \& J. Glazek, 1989: Terminology.- In: Bosak, P. et al. (eds.) Paleokarst - a systematic and regional review. Elsevier, pp. 25-32, Amsterdam.

Budd, D.A., 2002: The relative roles of compaction and early cementation in the destruction of permeability in carbonate grainstones: a case study from the Paleogene of west-central Florida, USA.- Journal Of Sedimentary Research, 72, 1, 116-128. https://doi. org/10.1306/061501720116

Callot, G., Guyon, A. \& D. Mousain, 1985: Inter-relation 
entre les aiguilles de calcite et hyphes mycéliens.Agronomie, 5, 209-216.

Cander, H., 1995: Interplay of water-rock interaction efficiency, unconformities, and fluid flow in a carbonate aquifer: Floridan aquifer system.- In: Budd, D.A. et al. (eds.) Unconformities and porosity in carbonate strata. AAPG memoir, 63, American Association of Petrolium Geologists, pp. 55-76, Tulsa.

Carew, L.W. \& J.E. Mylroie, 1994: Geology and karst of San Salvador island, Bahamas.- A field trip guidebook. San Salvador island, Bahamas: Bahamian field station, pp. 32.

Choquette, P. W. \& N. P. James, 1988. Introduction.- In: James N. P. \& P. W. Choquette (eds.) Paleokarst. Springer - Verlag, pp. 1 - 21, New York.

Collins, S.V., Reinhardt, E.G., Werner, C.L., Le Maillot, C., Devos, F. \& D. Rissolo, 2015: Late Holocene mangrove development and onset of sedimentation in the Yax Chen cave system (Ox Bel Ha) Yucatan, Mexico: Implications for using cave sediments as a sea-level indicator.- Palaeogeography, Palaeoclimatology, Palaeoecology, 438, 124-134. https://doi. org/10.1016/j.palaeo.2015.07.042

Csoma, A.E., Goldstein, R.H., Mindszenty, A. \& L. Simone, 2004: Diagenetic salinity cycles and sea level along a major unconformity, Monte Camposauro, Italy.- Journal of Sedimentary Research, 74, 6, 889903. https://doi.org/10.1306/051304740889

Csoma, A.É., Goldstein, R.H. \& L. Pomar, 2006: Pleistocene speleothems of Mallorca: implications for palaeoclimate and carbonate diagenesis in mixing zones.- Sedimentology, 53, 213-236. https://doi. org/10.1111/j.1365-3091.2005.00759.x

Drobne, K., 1977: Alveolines paleogenes de la Slovenie et de l'Istrie.- Mem. Suisses de Paleont., 99, pp. 174.

Esteban, M. \& C. F. Klappa, 1983: Subaerial exposure environments.- In: Scholle, P.A. et al. (eds.) Carbonate depositional environments. AAPG Memoir, 33, American Association of Petroleum Geologists, pp. $1-63$, Tulsa.

Esteban, M. \& J.L. Wilson, 1993: Introduction to karst systems and paleokarst reservoirs.- In: Fritz, R.D. et al. (eds.) Paleokarst and related hydrocarbon reservoirs. SEPM Core Workshop, 18, Society for Sedimentary Geology, pp. 1-9, Tulsa.

Fornós, J.J., Ginés, J. \& F. Gràcia, 2009: Present-day sedimentary facies in the coastal karst caves of Mallorca island (western Mediterranean).- Journal of Cave and Karst Studies, 71, 1, 86-99.

Frisia, S, 2015: Microstratigraphic logging of calcite fabrics in speleothems as tool for paleoclimate studies.- International journal of speleology, 44, 1, 1-16. https://doi.org/10.5038/1827-806X.44.1.1
Hill, C.A. \& F. Forti, 1997: Cave Minerals of the World.National Speleological Society, pp. 463, Huntsville.

Immenhauser, A., Creusen, A., Esteban, M. \& H.B. Vonhof, 2000a: Recognition and interpretation of polygenic discontinuity surfaces in the Middle Cretaceous Shu'aiba, Nahr Umr, and Natih formations of Northern Oman.- GeoArabia, 5, 2, 299-322.

Immenhauser, A., Schlager, W., Burns, S.J., Scott, R.W., Geel, T., Lehmann, J., Van der Gaast, S. \& L.J.A. Bolder-Schrijver, 2000b: Origin and correlation of disconformity surfaces and marker beds, Nahr Umr formation, northern Oman.- In: Alsharhan A.S. \& R.W. Scott (eds.) Middle East models of Jurassic/Cretaceous carbonate systems. Society for Sedimentary Geology, Special Publication, pp. 209-225. Tulsa.

Jež, J. \& B. Otoničar, 2018: Late Cretaceous geodynamics of the northern sector of the Adriatic Carbonate Platform (W Slovenia).- Newsletters on Stratigraphy, 51, 4, 381-410. https://doi.org/10.1127/ nos/2018/0439

Jež, J., 2011: Upper Cretaceous sedimentary evolution of the northern margin of the Adriatic Carbonate Platform (Western Slovenia).- PhD thesis. University of Ljubljana, pp. 185.

Jež, J., Otoničar, B., Fuček, L. \& B. Ogorelec, 2011: Late Cretaceous sedimentary evolution of a northern sector of the Adriatic Carbonate Platform (Matarsko Podolje, SW Slovenia).- Facies, 57, 3, 447-468. https://doi.org/10.1007/s10347-010-0249-6

Jones, B. 1989: Calcite rafts, peloids, and micrite in cave deposits from Cayman Brac, British-West-Indies.Canadian Journal of Earth Sciences, 26, 4, 654-664. https://doi.org/10.1139/e89-056

Jones, B., 1992: Caymanite, a cavity-filling deposit in the Oligocene-Miocene Bluff formation of the Cayman Islands.- Canadian Journal of Earth Sciences, 29, 4, 720-736. https://doi.org/10.1139/e92-062

Jones, B., 2010: Microbes in caves: agents of calcite corrosion and precipitation.- In: Pedley, H.M. \& M. Rogerson (eds.) Tufas and Speleothems: Unravelling the Microbial and Physical Controls, Special Publications, 336, Geological Society, pp. 7-30, London. https://doi.org/10.1144/SP336.2

Jones, B. \& C.F. Kahle, 1995: Origin of endogenic micrite in karst terrains: A case study from the Cayman Islands.- Journal of Sedimentary Research, A65, 2, 283-293. https://doi.org/10.1306/d426809f-2b26$11 \mathrm{~d} 7-8648000102 \mathrm{c} 1865 \mathrm{~d}$

Kambesis P.N. \& J.G. Coke IV, 2013: Overview of the Controls on Eogenetic Cave and Karst Development in Quintana Roo, Mexico.- In: Lace, M.J. \& J.E. Mylroie (eds.) Coastal Karst Landforms. Coastal Re- 
search Library, 5, Springer, pp. 347-378, Dordrecht. https://doi.org/10.1007/978-94-007-5016-6_16

Korpás, L., Lantos, M \& A. Nagymarosy, 1999: Timing and genesis of early marine caymanites in the hydrothermal palaeokarst system of Buda Hills, Hungary.- Sedimentary Geology, 123, 9-29. https://doi. org/10.1016/S0037-0738(98)00090-6

Košir, A. \& B. Otoničar, 2001: The evolution of Upper Cretaceous and Palaeogene synorogenic carbonate platforms in NW Dinaric foreland basin.- In: Dragičević I. \& I. Velić (eds.) Abstracts : $1^{\text {st }}$ scientific meeting on carbonate platform or carbonate platforms of Dinarids, $1^{\text {st }}-2^{\text {nd }}$ October 2001, Zagreb. Rudarsko-geološko-naftni fakultet, Prirodoslovnomatemetički fakultet, Institut za geološka istraživanja i Hrvatsko geološko društvo, 62-63, Zagreb.

Košir, A., 2004: Microcodium revisited: Root calcification products of terrestrial plants on carbonate-rich substrates.- Journal Of Sedimentary Research, 74, 6, 845-857. https://doi.org/10.1306/040404740845

Košir, A., Otoničar, B., Popit, T. \& M. Mišič, 2005: Vadozni karbonatni cementi v kvartarnih pobočnih sedimentih se lahko izločajo $\mathrm{z}$ biološko induciranimi procesi.- In: A. Hrovat (ed.) 17. posvetovanje slovenskih geologov, Ljubljana, 2005. Geološki zbornik, 18, Univerza v Ljubljani, Naravoslovnotehniška fakulteta, Oddelek za geologijo, pp. 57-59, Ljubljana.

Kovacs, S.E., 2017: Development and calibration of "calcite rafts" as a proxy for Holocene aquifer conditions in anchialine settings, Quintana Roo, Yucatán Peninsula, Mexico.- PhD thesis. McMaster University, pp. 131.

Lohmann, K.C., 1988: Geochemical patterns of meteoric diagenetic systems and their application to studies of paleokarst.- In: James N.P. \& P.W. Choquette (eds.) Paleokarst. Springer-Verlag, pp. 58-80, New York.

Loisy, C., Verrecchia, E.P. \& P. Dufour, 1999: Microbial origin for pedogenic micrite associated with a carbonate paleosol (Champagne, France).- Sedimentary Geology, 126, 1-4, 193-204. https://doi. org/10.1016/S0037-0738(99)00040-8

Loucks, R.G., 1999: Paleocave carbonate reservoirs: Origins, burial-depth modifications, spatial complexity, and reservoir implications.- AAPG Bulletin, 83, 11, 1795-1834. https://doi.org/10.1306/E4FD426F1732-11D7-8645000102C1865D

Magaš, N., 1968: Osnovna geološka karta SFRJ, list Cres 1 : 100 000.- Beograd.

Melim, L.A., Swart, P.K. \& G.P. Eberli, 2004: Mixingzone diagenesis in the subsurface of Florida and The Bahamas.- Journal of Sedimentary Research, 74, 6, 904-913. https://doi.org/10.1306/042904740904

Morse, J.W. \& F.T. Mackenzie, 1990: Geochemistry of sedi- mentary carbonates.- Development in sedimentology, 48, Elsevier, pp. 707, Amsterdam. https://doi. org/10.1016/0016-7037(93)90401-h

Mylroie, J.E. \& J.L. Carew, 1995a: Karst development on carbonate islands.- In: Budd, D.A. et al. (eds.) Unconformities and porosity in carbonate strata. AAPG Memoir, 63, American Association of Petroleum Geologists, pp. 55-76, Tulsa.

Mylroie, J.E. \& J.L. Carew, 1995b: Geology and karst geomorphology of San Salvador island, Bahamas.- Carbonates and Evaporites, 10, 2, 193-206. https://doi. org/10.1007/BF03175404

Osborne, R.A.L., 2000: Paleokarst and its significance for speleogenesis.- In: Klimchouk, A.B. et al. (eds.) Speleogenesis-Evolution of Karst Aquifers. National speleological society, pp. 113-123, Huntsville.

Osborne, R.A.L., 2008: Cave turbidites.- Acta carsologica, 37, 1, 42-50. https://doi.org/10.3986/ac.v37i1.158

Otoničar, B. \& A. Košir, 2016: Big phreatic paleokarstic cave of Ubac peninsula and other surface and subsurface paleokarstic phenomena adjacent to the cave (no. 2b) (Preliminary notes of reconnaissance survey).- In: Otoničar, B. \& P. Gostinčar (eds.) Paleokarst : abstracts \& guide book. $24^{\text {th }} \mathrm{In}$ ternational Karstological School Classical Karst, $13^{\text {th }}-14^{\text {th }}$ June 2016, Postojna. Založba ZRC SAZU and Karst Research Institute ZRC SAZU, 100-104, Postojna-Ljubljana.

Otoničar, B., 2006: Razvoj paleokrasa v zgornjekrednih apnencih Matarskega podolja in Slavnika = Paleokarst development in the Upper Cretaceous limestones of Matarsko Podolje and Slavnik.- $\mathrm{PhD}$ thesis. University of Ljubljana, pp. 309.

Otoničar, B., 2007: Upper Cretaceous to Paleogene forebulge unconformity associated with foreland basin evolution (Kras, Matarsko Podolje and Istria; SW Slovenia and NW Croatia).- Acta Carstologica, 36, 1, 101-120. https://doi.org/10.3986/ac.v36i1.213

Otoničar, B., 2008: Evolution of paleokarst related to a forebulge unconformity: An example from the late Cretaceous and Paleogene of Kras, Matarsko Podolje and Istria, southwest Slovenia and northwest Croatia.- In: Sasowsky, I.D. et al. (eds.) Karst form recent to reservoirs. Special Publication, 14, Karst Waters Institute, pp. 146-156, Leesburg.

Otoničar, B., 2016: Stratigraphy and evolution of the forebulge related paleokarst - introduction to excursions A and C.- In: Otoničar, B. \& P. Gostinčar (eds.) Paleokarst: abstracts \& guide book. $24^{\text {th }}$ International Karstological School Classical Karst, $13^{\text {th }}$ $14^{\text {th }}$ June 2016, Postojna. Založba ZRC SAZU and Karst Research Institute ZRC SAZU, 42-50, Postojna-Ljubljana. 
Palmer, A.N., 1995: Geochemical models for the originof macroscopic solution porosity in carbonate rocks. In: Budd, D.A. et al. (eds.) Unconformities and porosity in carbonate strata. AAPG memoir, 63, American Association of Petrolium Geologists, pp. 77-101, Tulsa.

Palmer, A.N., 2007: Cave Geology.- Cave book, pp. 454, Dayton.

Placer, L., 1981: Geološka zgradba jugozahodne Slovenije $=$ Geologic structure of southwestern Slovenia.- Geologija, 24, 27-60.

Placer, L., 1998: Contribution to the macrotectonic subdivision of the border region between Southern Alps and External Dinarides = Prispevek $\mathrm{k}$ makrotektonski rajonizaciji mejnega ozemlja med Južnimi Alpami in Zunanjimi Dinaridi.- Geologija, - 41, 223-255. https://doi.org/10.5474/geologija.1998.013

Smart, P.L., Beddows, P.A., Coke, J., Doerr, S., Smith, S. \& F.F. Whitaker, 2006: Cave development on the Caribbean coast of the Yucatan Peninsula, Quintana Roo, Mexico.- In: Harmon, R.S. \& C. Wicks (eds.) Perspectives on karst geomorphology, Hydrogeology, and Geochemistry - A tribute volume to Derek C. Ford and William B. White.- Special paper, 404, The geological society of America, pp. 105-128, Boulder. https://doi.org/10.1130/2006.2404(10)

Stampfli, G.M., Mosar, J., Marquer, D., Marchant, R., Baudin T. \& G. Borel, 1998: Subduction and obduction processes in the Swiss Alps.- Tectonophysics, 296, 1-2, 159-204. https://doi.org/10.1016/S00401951(98)00142-5

Stoessell, R. K., 1992: Effects of sulphate reduction on $\mathrm{CaCO}_{3}$ dissolution and precipitation in mixingzone fluids.- Journal of Sedimentary Petrology, 62, 5, 873-880.

Tarhule-Lips, R.F.A. \& D.C. Ford, 1998: Condensation Corrosion in Caves on Cayman Brac and Isla de Mona.Journal of Cave and Karst Studies, 60, 2, 84-95.

Thomas, C., 1999: Aspects hydrogéologiques du Yucatan (Mexique).- Karstologia, 34, 2, 9-22. https://doi. org/10.3406/karst.1999.2444

van Hengstum, P.J. \& D.B. Scott, 2011: Ecology of foraminifera and habitat variability in an underwater cave: distinguishing anchialine versus submarine cave environments.- Journal of Foraminiferal Research, 41, 3, 201-229. https://doi.org/10.2113/ gsjfr.41.3.201

van Hengstum, P.J., Scott, D.B., Gröckr, D.R. \& M.A. Charette, 2011: Sea level controls sedimentation and environments in coastal caves and sinkholes.- Marine Geology, 286, 35-50. https://doi.org/10.1016/j. margeo.2011.05.004

van Hengstum, P.J., Cresswell, J.N., Milne G.A. \& T.M.
Iliffe, 2019: Development of anchialine cave habitats and karst subterranean estuaries since the last ice age.- Scientific Reports, 9, 11907. https://doi. org/10.1038/s41598-019-48058-8

Veizer, J., Ala, D., Azmy, K., Bruckschen, P., Buhl, D., Bruhn, F., Carden, G.A.F., Diener, A., Ebneth, S., Godderis, Y., Jasper, T., Korte, C., Pawellek, F., Podlaha, O.G. \& H. Strauss, 1999: Sr-87/Sr-86, delta C-13 and delta O-18 evolution of Phanerozoic seawater.- Chemical Geology, 161, 1-3, 59-88. https:// doi.org/10.1016/S0009-2541(99)00081-9

Verrecchia, E.P., 2011: Pedogenic carbonates.- In: Reitner, J. \& V. Thiel (eds.) Encyclopedia of Geobiology. Springer Science+Busines Media B.V., pp. 721-725, Berlin/Heidelberg

Verrecchia, E.P. \& K.E. Verrecchia, 1994: Needle-fiber calcite - A critical-review and a proposed classification.- Journal of Sedimentary Research, Section A - Sedimentary Petrology and Processes, 64, 3, 650-664. https://doi.org/10.1306/D4267E33-2B2611D7-8648000102C1865D

Viehmann, I., Ghergari, L. \& B.P. Onac, 1997: Crystallographical observations on calcite rafts from three Romanian caves.- In: Jeannin, P.Y. (ed.) Abstracts : 12th International congress of speleology, $10^{\text {th }}-17^{\text {th }}$ August 1997, La Chaux-de-Fonds, International Union of Speleology / Swiss Speleological Society, 227-230, La Chaux-de-Fonds.

Vlahović, I., Tišljar, J., Velić, I. \& D. Matičec, 2005: Evolution of the Adriatic Carbonate Platform: Palaeogeography, main events and depositional dynamics.Palaeogeography Palaeoclimatology Palaeoecology, 220, 3-4, 333-360. https://doi.org/10.1016/j.palaeo.2005.01.011

Vogel, P.N., Mylroie, J.E. \& J.L. Carew, 1990: Limestone petrology and cave morphology on San Salvador Island, Bahamas.- Cave Science, 17, 1, 19-30.

Whitaker, F. F. \& P. L. Smart, 1998: Hydrology, geochemistry and diagenesis of fracture blue holes, South Andros, Bahamas.- Cave and karst science, 25, 2, $75-82$.

Whitaker, F.F. \& P.L. Smart, 1997: Hydrogeology of the Bahamian arhipelago.- In: H.L. Vacher \& T.M. Quinn (eds.) Geology and hydrogeology of carbonate islands. Developments in sedimentology, 54, Elsevier, pp. 183-216, Amsterdam.

White, J.H., Domínguez-Villar, D. \& A. Hartland, 2021: Condensation corrosion alters the oxygen and carbon isotope ratios of speleothem and limestone surfaces.- Results in Geochemistry, 2, 100008. https:// doi.org/10.1016/j.ringeo.2021.100008

Wright, V.P., 1986: Paleosols - their recognition and in- 
terpretation.- Blackwell Scientific Publications, pp. 315, Oxford.

Wright, V.P., Vanstone, S.D. \& J.D. Marshall, 1997: Contrasting flooding histories of Mississippian carbonate platforms revealed by marine alteration effects in palaeosols.- Sedimentology, 44, 5, 825-842.

Wright, V.P., 2002: Dissolution and porosity development in carbonates.- In: Gabrovšek F. (ed.) Evolution of karst: from prekarst to cessation. Carsologica. Založba ZRC SAZU, pp. 43-59, Postojna-Ljubljana.

Wright, V.P. \& M.E. Tucker, 1991: Calcretes: an introduction.- In: Wright, V.P. \& M.E. Tucker (eds.) Cal- cretes.- Blackwell Scientific Publications, pp. 1-22, Oxford.

Wright, V.P. \& P.L. Smart, 1994: Paleokarst (dissolution diagenesis): its occurence and hydrocarbon expoloration significance.- In: Wolf K.H. \& G.V. Chilingarian (eds.) Diagenesis, IV. Developments in sedimentology, 51, Elsevier, pp. 447-517, Amsterdam - New York.

Zupan Hajna, N., 2014: Nepopolno raztapljanje karbonatnih kamnin v kraških jamah Slovenije.- Carsologica, Založba ZRC SAZU in Inštitut za raziskovanje krasa ZRC SAZU, pp. 222, Postojna - Ljubljana. 